\title{
DETERMINAN PERILAKU KONSUMSI PANGAN MASYARAKAT DI DAERAH ISTIMEWA YOGYAKARTA (DIY) DAN NUSA TENGGARA TIMUR (NTT)
}

\section{DETERMINANTS OF FOOD CONSUMPTION BEHAVIOUR IN YOG- YAKARTA (DIY) AND NUSA TENGGARA TIMUR (NTT)}

\author{
Tuti Ermawati, Jiwa Sarana \\ Peneliti pada Pusat Penelitian Ekonomi LIPI \\ tuti_ermawati@yahoo.com,saranajiwa@yahoo.com
}

\begin{abstract}
Abstrak
Kajian ini menganalisis determinan perilaku konsumsi pangan masyarakat di dua wilayah yang memiliki pola konsumsi pangan yang berbeda yaitu DI Yogyakarta (DIY) dan Nusa Tenggara Timur (NTT). Di DIY perilaku konsumsi pangan sudah mengarah pada pola pangan sehat sehingga analisis mengarah determinan perilaku konsumsi pangan sehat. Sementara di NTT, pola perilaku konsumsi masih berorientasi pada makanan pokok sehingga analisis mengarah pada faktor-faktor yang memengaruhi konsumsi pangan pokok non beras. Metode analisis yang digunakan adalah analisis jalur (Path Analysis) dengan pendekatan teori perilaku. Berdasarkan hasil analisis, konsumsi pangan sehat di DIY dipengaruhi oleh niat atau intensi Ibu Rumah Tangga (IRT) dalam menyajikan makanan. Intensi IRT dipengaruhi oleh sikap yang terbentuk karena adanya pemahanan dan dukungan kuat dari orang terdekat (suami). Selain itu, intensi juga sangat dipengaruhi oleh kontrol lingkungan terutama kebiasaan keluarga yang lebih suka mengkonsumsi makanan olahan sendiri. Sementara di NTT, intensi IRT dalam menyajikan makanan pokok non beras dipengaruhi oleh sikap dan kontrol lingkungan. Sikap sangat dipengaruhi oleh keterampilan dan pemahaman IRT, sedangkan kontrol lingkungan dipengaruhi kebiasaan keluarga mengkonsumsi makanan pokok non beras serta upacara keagamaan. Berdasarkan hal tersebut di atas, maka yang perlu dilakukan oleh pemerintah agar perilaku konsumsi pangan sesuai dengan yang diharapkan, antara lain: Pertama, peningkatan sosialisasi tentang pola pangan harapan (PPH) di DIY dan sosialisasi penganekaragaman makanan pokok di NTT. Kedua, adanya pelatihan pengolahan makanan sehat yang bervariasi bagi para ibu rumah tangga karena ternyata keluarga lebih menyukai makanan olahan sendiri dibandingkan dengan makanan instan.
\end{abstract}

Kata Kunci: Perilaku, Konsumsi, Pangan, Pola Pangan Harapan (PPH), Nutrisi

Klasifikasi JEL : D19, D91, Q18

\begin{abstract}
The study analyzes the determinants of people's food consumption behavior in two regions that have different food consumption patterns, namely DI Yogyakarta (DIY) and Nusa Tenggara Timur (NTT). In DIY, food consumption behavior has led to healthy food patterns so that analysis leads to determinants of healthy food consumption behavior. While in NTT, consumption behavior pattern is still oriented to staple food so that analysis leads to determinant of non staple food consumption of rice. The analytical method used in this study is path analysis with behavioral theory approach. Based on path analysis, the consumption of healthy family food in DIY is influenced by the intention of housewife in serving food. The intention of the housewife is influenced by the attitude formed by the knowledge and strong support from the closest person (husband). In addition, the intention is also strongly influenced by environmental control, especially family habits that prefer to consume their own processed foods. While in NTT, the intentions of housewives in serving non-rice staple food are influenced by attitude and environmental control. Attitudes are influenced by the skills and knowledges of housewives. While environmental control influenced family habits of consuming non-rice staple food and religious ceremonies. Hence, the government needs to do food consumption in accordance with the expectation, among others: First, increase promotion about the Desirable Dietary Pattern (DDP) in DIY and socialization of diversification of staple foods in NTT. Second, setting up training of varies healthy food processing for housewives considering that actually family members prefer processed food compared to instant food.
\end{abstract}

Keywords: Behavior, Consumption, Food, Desirable Dietary Pattern (PPH), nutrition

JEL Classification: D19, D91, Q18 


\section{PENDAHULUAN}

Pola perilaku konsumsi pangan rumah tangga merupakan hal yang sangat penting karena akan berpengaruh terhadap kecukupan gizi, kalori, kesehatan dan tumbuh kembangnya suatu masyarakat. Konsumsi pangan yang berlebih dan hanya bertumpu pada salah satu jenis makanan akan mengakibatkan tubuh menghadapi berbagai masalah kesehatan seperti obesitas yang berimplikasi pada munculnya penyakit jantung, kolesterol dan sebagainya. Sebaliknya, jika kalori yang dikonsumsi tidak cukup dan tidak bervariasi akan menimbulkan berbagai macam penyakit terutama kekurangan gizi yang dapat mengganggu tumbuh kembangnya masyarakat terutama pertumbuhan remaja dan anak-anak, padahal tumbuh kembang anak-anak dan remaja merupakan aset yang sangat penting bagi pertumbuhan suatu negara.

Dengan demikian maka pola perilaku konsumsi pangan sehat dan mencukupi menjadi penting untuk diperhatikan oleh pemerintah. Sebagaimana yang dikemukakan oleh Fogel (2004) dalam penelitiannya menyatakan bahwa pertumbuhan pendapatan per kapita yang terjadi di Inggris dan Perancis saat ini salah satunya terjadi karena adanya peningkatan persediaan jumlah kalori untuk bekerja selama 200 tahun yang lalu. Pemberian kalori yang cukup akan meningkatkan produktivitas tenaga kerja dan diperkirakan oleh Fogel (2004) bahwa perbaikan gizi tersebut memberikan kontribusi sebesar 30\% terhadap pertumbuhan per kapita di Inggris. Sebaliknya, menurut Bloom dan Sachs (1998) menyatakan bahwa keterbelakangan pertumbuhan di negara-negara Afrika terjadi karena penyakit, kependudukan dan geografis, dimana penurunan pertumbuhan ekonomi setiap tahunnya berhubungan erat dengan tingginya angka prevalensi penyakit malaria.

Konsumsi pangan menurut Badan Ketahanan Pangan (2014) adalah sejumlah makanan dan minuman yang dikonsumsi seseorang, kelompok, atau penduduk untuk memenuhi kebutuhan gizinya. Pangan yang dikonsumsi oleh rumah tangga idealnya harus bergizi, beragam, sehat dan aman (B2SA) seperti yang telah ditetapkan oleh pemerintah sehingga pola pangan sehat dapat tercapai. Di Indonesia, salah satu cara untuk melihat seberapa cukup dan sehat makanan yang dikonsumsi oleh masyarakat di suatu daerah adalah dengan melihat nilai Pola Pangan Harapan atau PPH. Pola Pangan Harapan adalah pola konsumsi pangan yang beragam yang didasarkan pada sumbangan energi baik secara absolut maupun relatif dari konsumsi pangan masyarakat dengan nilai ideal PPH 100. Semakin tinggi nilai PPH masyarakat menunjukkan semakin baik angka kecukupan gizinya dan sebaliknya semakin rendah angka PPH maka angka kecukupan gizi masyarakat semakin buruk.

Rata-rata nilai PPH Indonesia tahun 2011 hingga 2015 sebesar 83,82, tertinggi pada tahun 2011 sebesar 85,6 kemudian turun pada tahun 2012-2014 seiring dengan turunnya daya beli masyarakat, dan kembali naik menjadi 85,2 pada tahun 2015. Perkembangan PPH setiap daerah berbeda, ada yang mengalami tren positif dan negatif. Salah satu daerah yang mengalami perkembangan nilai PPH yang positif adalah DI Yogyakarta dimana rata-rata nilai PPH tahun 2009-2014 sebesar 85,55 dengan nilai PPH terendah terjadi pada tahun 2009 sebesar 77,8 dan tertinggi di tahun 2014 sebesar 91,9. Sementara itu, salah satu daerah yang trennya negatif yakni NTT dengan nilai PPH rata-rata tahun 2009-2014 sebesar 75,42. Pada tahun 2009, nilai PPH NTT telah mencapai 74 namun nilai tersebut turun menjadi 68 pada tahun 2014.

Tingginya nilai PPH di DIY terutama pada tahun 2014 sangat wajar terjadi dikarenakan konsumsi makan masyarakat sudah menuju pola pangan sehat dengan total kalori pangan yang dikonsumsi lebih besar dibandingkan dengan NTT. Di DIY, pada tahun 2014 konsumsinya telah mencapai 2.233 kilo kalori per kapita per hari dengan komposisi pangan yang cukup berimbang yaitu $62 \%$ berasal dari padi-padian, umbi-umbian $2 \%$, pangan hewani $11 \%$, sayur dan buah $5 \%$ dari total kalori. Sementara di NTT, jumlah kalori per kapita yang di konsumsi baru mencapai 1.866 kilo kalori/hari, dengan komposisi pangan yang masih mengarah pada konsumsi makanan pokok (karbohidrat), yaitu $72 \%$ berasal dari padi-padian, $3 \%$ umbi-umbian, $5 \%$ sayur dan buah, serta konsumsi pangan hewani sebesar 5\% dari total kalori sehingga tidak banyak variasi makanan yang dikonsumsi. 
Banyak faktor yang berpengaruh terhadap perilaku konsumsi pangan masyarakat, baik internal maupun eksternal. Faktor internal yang berpengaruh antara lain keinginan, pengetahuan atau kesadaran ibu rumah tangga untuk menyajikan makanan sehat untuk keluarganya, perilaku ibu rumah tangga (IRT) dalam memproduksi makanan, kondisi ekonomi keluarga terutama harga dan kemampuan RT dalam membeli makanan sehat, dan lain sebagainya. Sementara untuk eksternal yakni kondisi lingkungan sekitar, seperti yang dikemukakan oleh Kelly et al (2006) bahwa agen sosial seperti keluarga, guru, teman dan pemerintah memiliki peran sangat berpengaruh terhadap pola pangan sehat.

Berdasarkan hal tersebut di atas maka tulisan kali ini menganalisis pola perilaku konsumsi pangan rumah tangga di Daerah Istimewa Yogyakarta (DIY) dan di Nusa Tenggara Timur (NTT) serta faktor yang memengaruhinya baik internal maupun eksternal. Dua wilayah tersebut dijadikan sebagai fokus kajian karena memiliki pola perilaku pangan yang berbeda. Di DIY perilaku konsumsi pangan sudah mengarah pada PPH sehingga analisis akan mengarah pada faktorfaktor yang memengaruhi perilaku konsumsi pangan sehat. Sementara di NTT, pola perilaku konsumsi masih berorientasi pada makanan pokok sehingga analisis akan mengarah pada faktorfaktor yang memengaruhi diversifikasi pangan pokok. Dengan teridentifikasinya faktor yang memengaruhi pola perilaku konsumsi pangan di tingkat rumah tangga, diharapkan pemerintah lebih mudah dalam mensosialisasikan B2SA kepada masyarakat sehingga perilaku konsumsi pangan masyarakat berubah kearah makanan sehat.

\section{TINJAUAN PUSTAKA}

\section{Perilaku Konsumsi Masyarakat dalam Kerangka Teori}

Perilaku seseorang dalam melakukan sebuah tindakan sangat dipengaruhi oleh intensi atau niat. Teori tersebut dikembangkan oleh Fishbein dan Ajzen (1975) dalam Teori Tindakan Beralasan atau Theory of Reasoned Action (TRA) yang mengemukakan bahwa perilaku seseorang sangat dipengaruhi oleh niat, dimana niat sendiri tergantung pada sikap serta norma subjektif. Namun kemudian, Azjen melihat bahwa TRA kadang tidak terwujud ketika perilaku tidak sepenuhnya dikontrol oleh individu, sehingga Azjen (1991) menambahkan variabel kontrol perilaku sebagai variabel yang juga memengaruhi niat serta perilaku seseorang yang lebih dikenal sebagai teori perilaku yang direncanakan atau Theory of Planned Behavior (TPB). (lihat Gambar $1)$.

Hogg dan Vaughan (2005) mengartikan niat sebagai pernyataan internal untuk melakukan sesuatu. Terkait dengan perilaku konsumsi

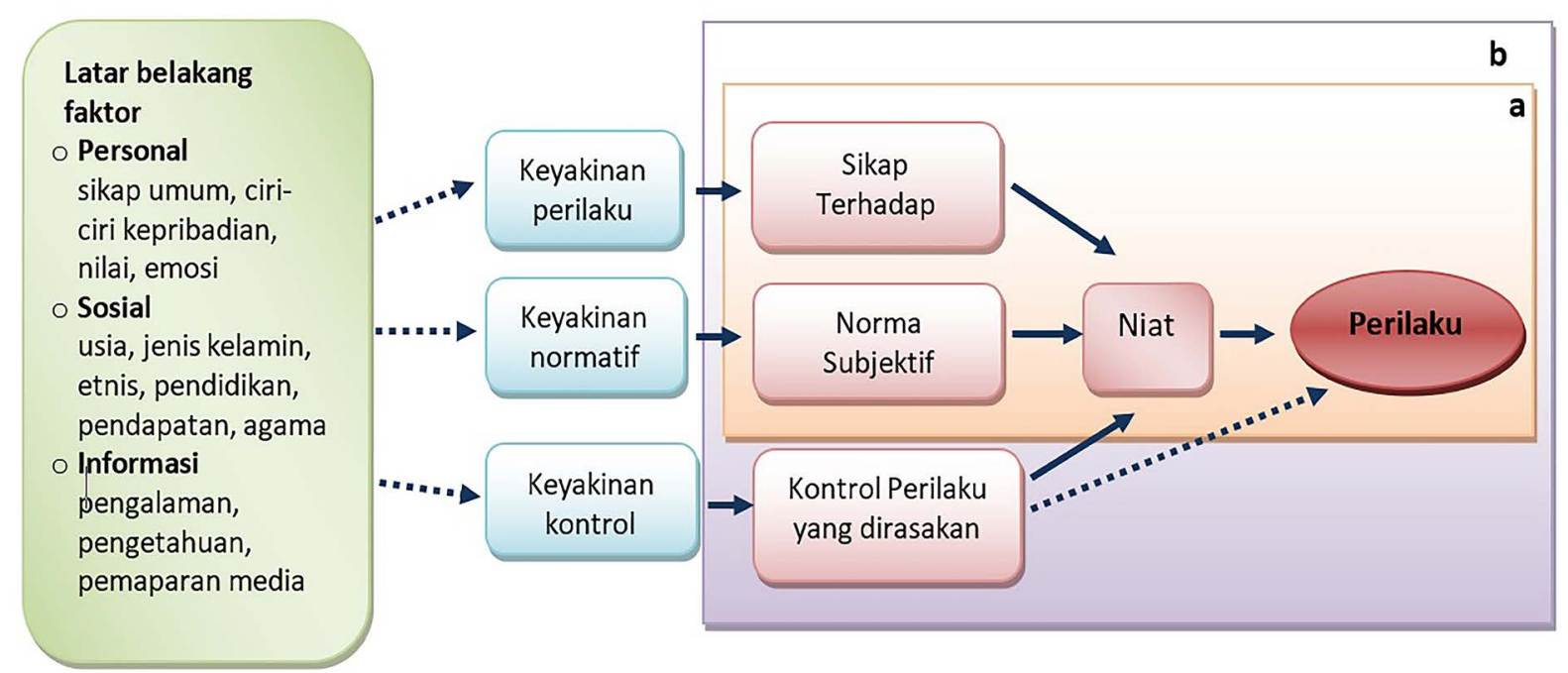

Sumber: Azjen (2005)

Gambar 1. Peran background factor pada theory of Planned Behavior 
makanan pokok, niat adalah rencana atau keinginan yang kuat untuk mengkonsumsi makanan pokok tertentu. Sementara sikap adalah tindakan untuk merespon secara menyenangkan/positif atau tidak menyenangkan terhadap benda, orang, institusi atau kejadian (Azjen, 2005). Jadi sikap mengkonsumsi makanan adalah respon individu baik positif/tidak ketika mengkonsumsi makanan tertentu. Sementara norma subjektif menurut Baron dan Byrne (2005) adalah persepsi individu apakah orang lain akan mendukung atau tidak mendukung terwujudnya suatu tindakan tertentu. Norma subjektif dalam mengkonsumsi makanan pokok dapat diartikan sebagai lingkungan sosial yang ada di masyarakat dalam mendukung atau tidak untuk mengkonsumsi makanan pokok tertentu. Faktor lain yang berpengaruh terhadap niat adalah kontrol perilaku yang dirasakan (Perceived Behavior Control/ PBC) yaitu ukuran sejauhmana individu percaya tentang mudah atau sulitnya bertingkah laku tertentu (Hogg dan Vaughman, 2005).

Dalam perkembangannya banyak faktor yang berpengaruh terhadap intensi dan juga perilaku. Sikap, norma subjektif dan kontrol perilaku yang memengaruhi intensi, sangat ditentukan oleh keyakinan (belief). Ada 3 variabel yang memengaruhi keyakinan seseorang terhadap suatu hal, antara lain: pertama, variabel personal (sikap secara umum, ciri-ciri kepribadian, nilai emosi, kecerdasan), kedua adalah variabel sosial (usia, jenis kelamin, etnis, pendidikan, pendapatan dan agama), ketiga, variabel informasi (pengalaman, pengetahuan, dan pemaparan dari media). Meskipun ketiga variabel tersebut tidak masuk dalam Theory of Planned Behavior (TPB), namun dapat menjelaskan secara lebih detail mengenai faktor-faktor yang memengaruhi perilaku (lihat Gambar 1).

Selanjutnya Montana dan Kasprzyk (2008) mengembangkan teori model perilaku yang terintegrasi yang merupakan penggabungan antara teori tindakan beralasan (TRA) dan perilaku yang direncanakan (TPB). Dalam teori model perilaku yang terintegrasi tersebut, ada variabel eksternal yang memengaruhi perilaku masyarakat/ seseorang antara lain adalah variabel demografi, sikap terhadap target, sifat kepribadian, serta variabel perbedaan individu yang lain (lihat Gambar 2).

Sehubungan dengan perilaku masyarakat dalam mengkonsumsi pangan Vindigni, Janssen dan Jager (2002) menggambarkan perilaku sebagai sebuah siklus yang terus berproses, dimana perilaku banyak individu di tingkat mikro dan juga makro akan saling memengaruhi satu dengan yang lainnya. Lingkungan termasuk

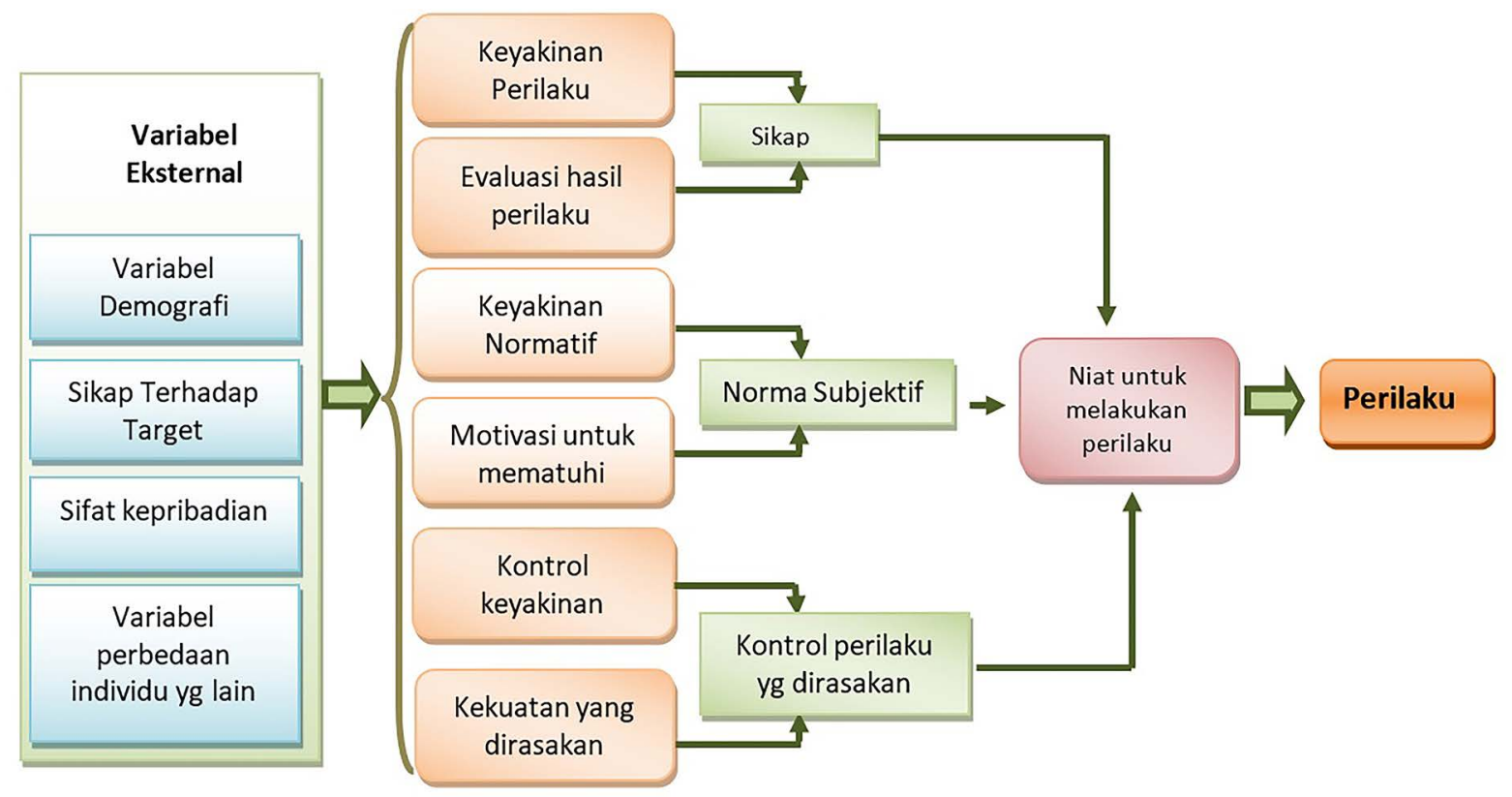

Sumber: Montana dan Kasprzyk (2008)

Gambar 2. Teori Integrasi Perilaku 
budaya, institusi, demografi, teknologi, dan kondisi ekonomi menggambarkan kondisi tempat tinggal masyarakat atau rumah tangga. Para rumah tangga dihadapkan pada kesempatan/peluang, kemampuan dan kebutuhan konsumsi yang berbeda antara satu individu dengan individu yang lainnya sehingga kadang ada perbedaan antara hasil yang diharapkan dengan perilaku aktual mereka (lihat Gambar 3). Perilaku konsumen sendiri menurut Kotler dan Keller (2008) adalah perilaku individu, kelompok, dan organisasi dalam memilih, membeli, menggunakan serta menempatkan barang, jasa, ide atau pengalaman untuk memuaskan keinginan dan kebutuhan mereka.

Dalam hal perilaku konsumsi pangan, Randal dan Sanjur (1981) menyatakan bahwa perilaku seseorang dalam melakukan konsumsi makanan sangat tergantung terhadap preferensi orang tersebut terhadap makanan yang akan dikonsumsi, yang dipengaruhi antara lain oleh: pertama, karakteristik individu seperti umur, jenis kelamin, pendidikan, pendapatan, pengetahuan gizi, keterampilan memasak, dan tingkat kesehatan. Kedua, karakteristik makanan (rasa, rupa, tekstur, harga, tipe makanan, bentuk, bumbu, dan kombinasi makanan). Ketiga, karakteristik lingkungan (musim, pekerjaan, mobilitas, perpindahan penduduk, jumlah rumah tangga, dan tingkat sosial di masyarakat) (lihat Gambar 3).

Meningkatnya pertumbuhan ekonomi yang salah satunya ditandai dengan semakin banyaknya pasar modern yang dibangun memudahkan masyarakat terutama para ibu rumah tangga yang bekerja untuk memilih makanan yang menjadi preferensinya. Dengan kesibukan yang ada, mereka cenderung memilih makanan yang mudah untuk disajikan (convenience food consumption). Menurut Brunner, Horst, dan Siegrist (2010), convenience food consumption adalah produk makanan yang menghemat waktu dan usaha dalam persiapan, konsumsi, dan pembersihannya. Ada 4 pendekatan yang dapat digunakan untuk melihat perilaku masyarakat terutama para ibu dalam mengkonsumsi makanan yang mudah untuk disajikan, antara lain adalah pendekatan: produksi rumah tangga, orientasi kemudahan, sistem pangan, dan budaya konsumen. (Schubert, Jennaway, dan Johnson, 2010).

Mengadopsi teori yang dikembangkan oleh Ajzen (2005), Randal dan Sanjur (1981) serta Schubert, Jennaway, dan Johnson (2010), maka

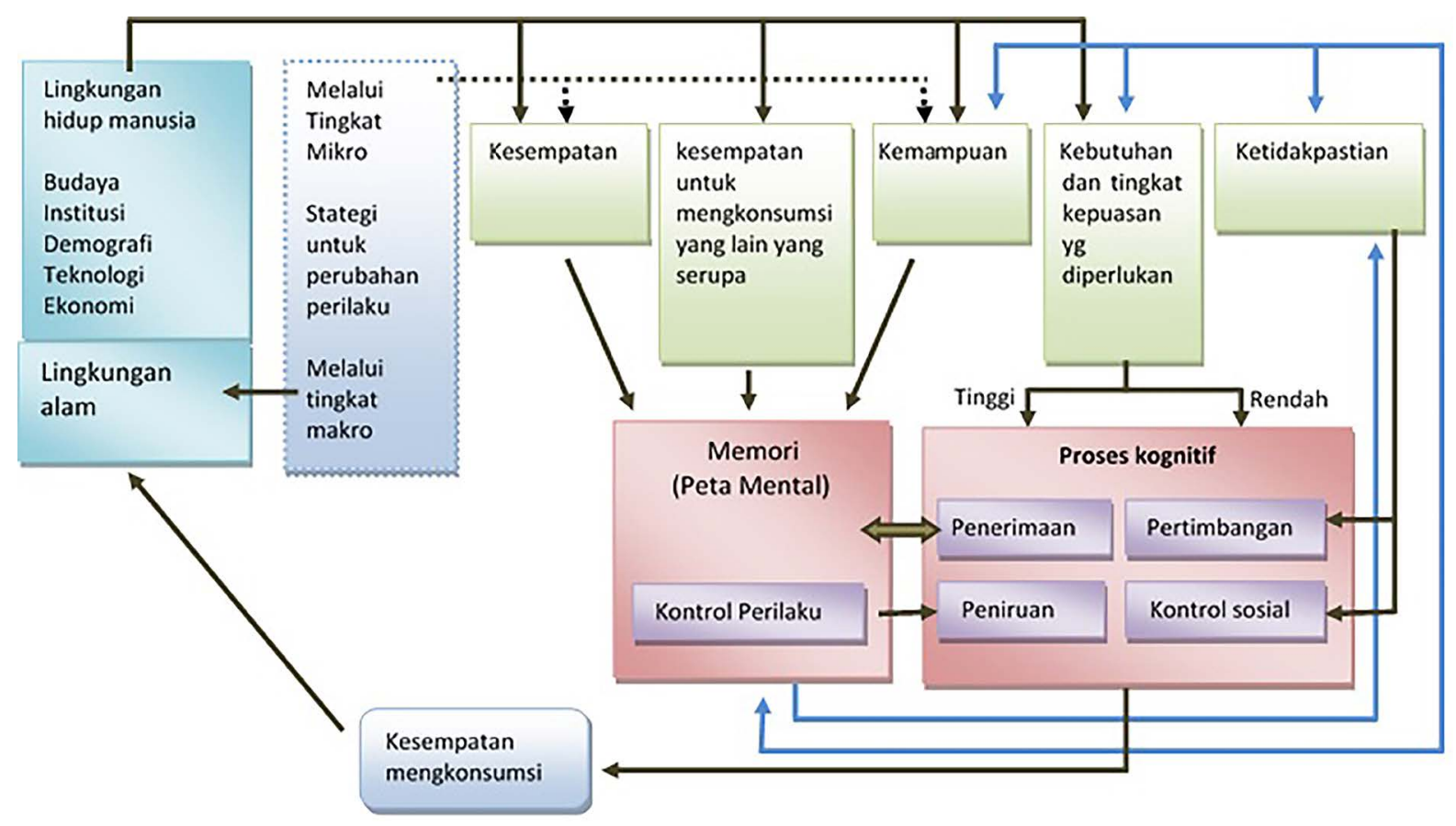

Sumber: Vindigni, Janssen dan Jager (2002)

Gambar 3. Model Konseptual Perilaku Konsumen 
model yang akan dibangun dalam tulisan ini adalah seperti pada Gambar 4. Perilaku konsumsi pangan sebuah rumah tangga sangat dipengaruhi oleh keinginan seorang ibu rumah tangga dalam menentukan jenis makanan yang akan disajikan untuk keluarganya. Ibu memiliki peran yang sangat penting dalam penyajian makanan sebagaimana yang dikemukan oleh Chapman \& Ogden (2009) bahwa menyajikan makanan yang baik untuk keluarga merupakan bagian dari tanggung jawabnya sebagai seorang ibu yang baik. Keinginan atau intensi tersebut dipengaruhi oleh sikap yang dilatarbelakangi oleh karakteristik rumah tangga, proses produksi pangan, dan kondisi ekonomi rumah tangga itu sendiri.

Selain sikap, keinginan seorang ibu rumah tangga dalam menyajikan makan juga dipengaruhi oleh norma yang dibangun oleh instansi pemerintah dan lingkungan sekitar dimana rumah tangga tersebut berada. Kontrol perilaku seperti sosial budaya, budaya dalam rumah tangga sendiri, dan sistem pangan yang terbangun juga memengaruhi keinginan ibu rumah tangga dalam menyajikan pangan untuk keluarganya. Sikap yang diambil oleh ibu rumah tangga tidak bisa dilepaskan dari norma dan kontrol sosial di masyarakat, begitupun dengan kontrol sosial yang memengaruhi norma, dan sebaliknya antara sikap, norma dan perilaku kontrol saling terkait satu dengan yang lain (Gambar 4).

\section{METODE PENELITIAN}

\section{Metode Analisis}

Dalam tulisan ini metode yang digunakan adalah analisis jalur (path analisis) yang merupakan alat analisis untuk melihat besarnya kontribusi dari suatu hubungan kausalitas yang ditunjukkan melalui koefisien jalur dalam sebuah diagram. Alat analisis ini pertama kali dikembangkan oleh Sewel Wright pada tahun 1934. Menurut Retherford (1993) analisis jalur adalah teknik untuk menganalisis hubungan sebab akibat yang tejadi pada sebuah regresi berganda ketika variabel bebasnya memengaruhi variabel tergantung baik secara langsung maupun tidak langsung.

Dalam path analysis, ada beberapa variabel yang digunakan, antara lain: Pertama, variabel eksogeneous (variabel independen) adalah variabel yang tidak ada penyebab eksplisitnya atau tidak ada anak panah yang menuju variabel tersebut. Kedua, variabel endogenous (variabel dependen) yaitu variabel tergantung dimana ada anak panah yang menuju pada variabel tersebut. Ketiga, variabel laten adalah variabel penyebab yang tidak dapat diobervasi secara langsung.

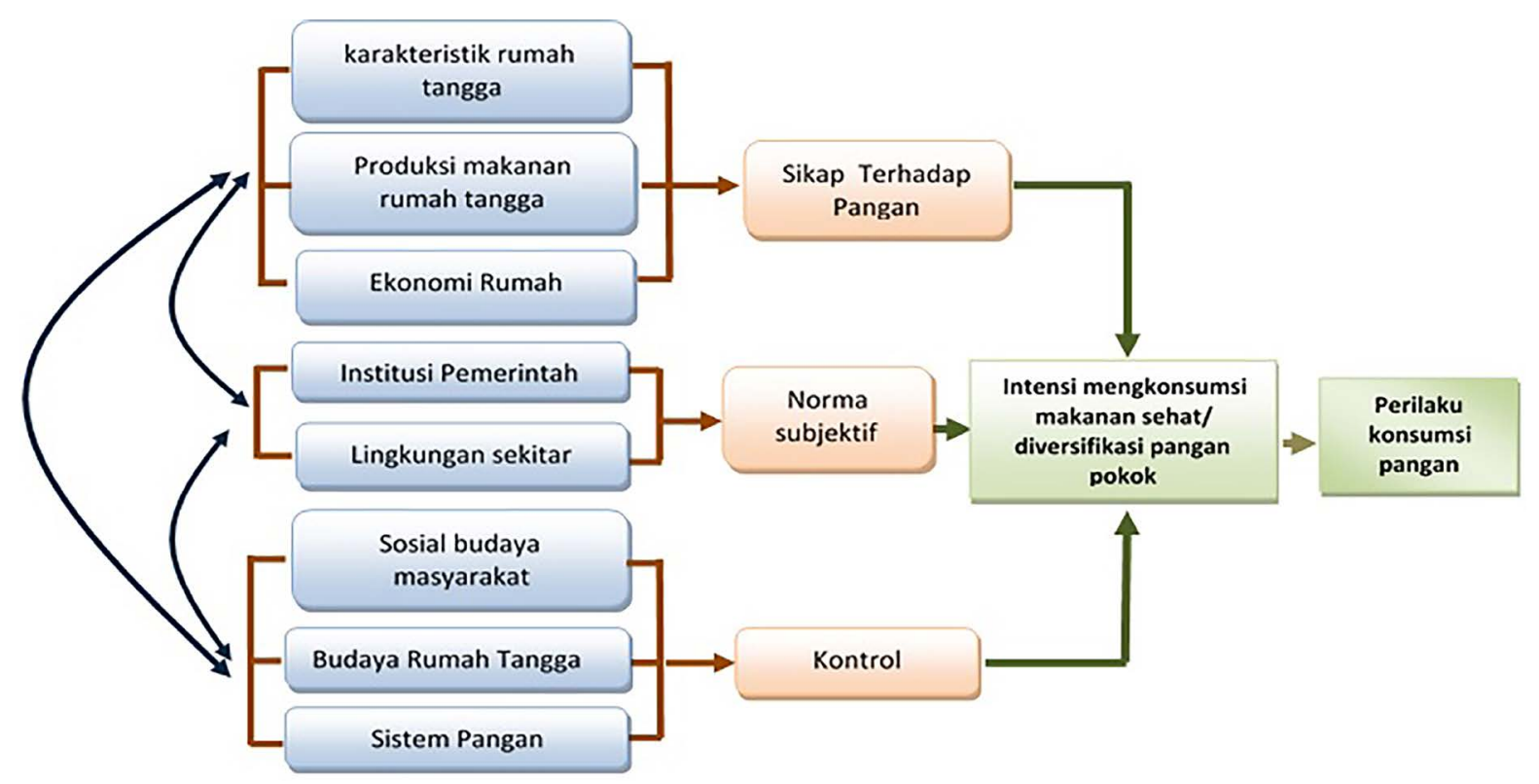

Sumber: Adaptasi dari Azjen (2005), Randal dan Sanjur (1981), serta Schubert, Jennaway, dan Johnson (2010).

Gambar 4. Model Perilaku Konsumsi Pangan 
Variabel mediator (intervening) adalah variabel yang secara teoritis memengaruhi hubungan antar variabel independen dengan variabel dependen menjadi hubungan yang tidak langsung dan tidak dapat diamati dan diukur. Secara sederhana, path analysis dapat digambarkan dalam sebuah diagram jalur seperti pada Gambar 5. Dengan persamaan yang dibangun $Y=\alpha_{1} X_{1}+\alpha_{2} X_{2}+\alpha_{3} X_{3}+\mathcal{E}$, dimana ada tiga variabel yaitu $X_{1}, X_{2}$, dan $X_{3}$ sebagai variabel eksogeneous memiliki hubungan kausalitas dengan variabel endogeneous (Y) dengan variabel residual $\varepsilon$, sementara antara variabel $X_{1}$ dengan $X_{2}, X_{1}$ dengan $X_{3}, X_{2}$ dengan $\mathrm{X}_{1}$ dan $\mathrm{X}_{2}$ dengan $\mathrm{X}_{3}$ memiliki hubungan korelasi.

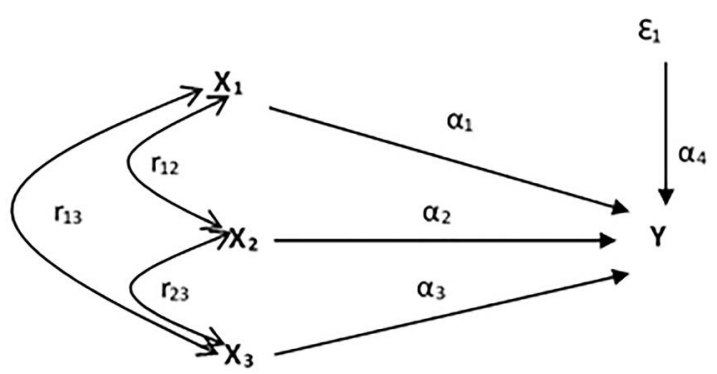

Gambar 5. Hubungan Kausalitas Antara X1, X2, X3 Terhadap Y dalam Diagram Jalur

Dalam path analysis, ada beberapa jenis model yang bisa digunakan, antara lain model dekomposisi, model mediasi, model regresi berganda, model kombinasi regresi berganda dan mediasi, model kompleks, model rekursif dan non rekursif, serta model trimming. Dalam tulisan kali ini, model yang akan digunakan adalah model trimming yaitu model analisis jalur yang mengeluarkan variabel eksogen yang tidak signifikan di dalam model. Adapun variabel dan parameter yang digunakan dalam tulisan ini sebagai berikut: (lihat Tabel 1)

\section{Data}

Data yang digunakan adalah data primer berupa kuesioner dengan jumlah 199 responden ibu rumah tangga(IRT) di DIY dan 150 responden IRT di NTT yang tersebar di wilayah perkotaan dan perdesaan. Ibu rumah tangga (IRT) dijadikan sebagai target responden karena memiliki pengaruh besar dalam memutuskan dan menyajikan makanan yang akan dikonsumsi oleh keluarganya. Selain itu, para IRT juga menjadi sasaran program yang dijalankan oleh Badan Ketahanan Pangan dan Penyuluhan (BKPP) baik sosialisasi tentang makanan beragam, bergizi, seimbang dan aman (B2SA) dan program Kawasan Rumah Pangan Lestari (KRPL). Adapun fokus analisis, di Propinsi DIY akan mengarah pada pola perilaku RT dalam mengkonsumsi pangan sehat, sementara di NTT akan menganalisa perilaku RT dalam konsumsi makanan pokok.

Tabel 1 Variabel dan parameter Perilaku Konsumsi Pangan Sehat di DIY

\begin{tabular}{|c|c|c|c|}
\hline No & \multicolumn{2}{|l|}{ Variabel } & Parameter \\
\hline 1 & Endogen & $\begin{array}{l}\text { Perilaku konsumsi makan- } \\
\text { an sehat/pokok }\end{array}$ & - Keluarga mengkonsumsi makanan sehat/pokok setiap hari \\
\hline \multirow[t]{2}{*}{2} & \multirow[t]{2}{*}{ Eksogen } & $\begin{array}{l}\text { a. Intensi mengkonsumsi } \\
\text { makanan sehat/diversifi- } \\
\text { kasi makanan pokok }\end{array}$ & $\begin{array}{l}\text { - Dalam } 1 \text { minggu ke depan akan menyiapkan makanan sehat/diversifikasi } \\
\text { makanan pokok untuk keluarga setiap hari }\end{array}$ \\
\hline & & $\begin{array}{l}\text { b. Sikap } \\
\text { - Karakteristik Rumah } \\
\text { Tangga }\end{array}$ & $\begin{array}{l}\text { - Makanan yang sehat/diversifikasi makanan pokok sangat penting untuk } \\
\text { dikonsumsi oleh keluarga } \\
\text { - Makanan sehat/diversifikasi makanan pokok membuat tubuh selalu sehat } \\
\text { - Makanan sehat /diversifikasi makanan pokok dapat memenuhi kebutuhan } \\
\text { gizi tubuh } \\
\text { - Makanan sehat/diversifikasi makanan pokok membuat tubuh lebih berenergi// } \\
\text { kuat } \\
\text { - Lebih memilih memasak makanan sendiri dibandingkan dengan membeli } \\
\text { dari luar } \\
\text { - Lebih memilih makanan sehat dibandingkan dengan menyajikan fast food/ } \\
\text { makanan cepat saji } \\
\text { - Senang memasak makanan sehat dibandingkan melakukan kegiatan lainnya }\end{array}$ \\
\hline
\end{tabular}




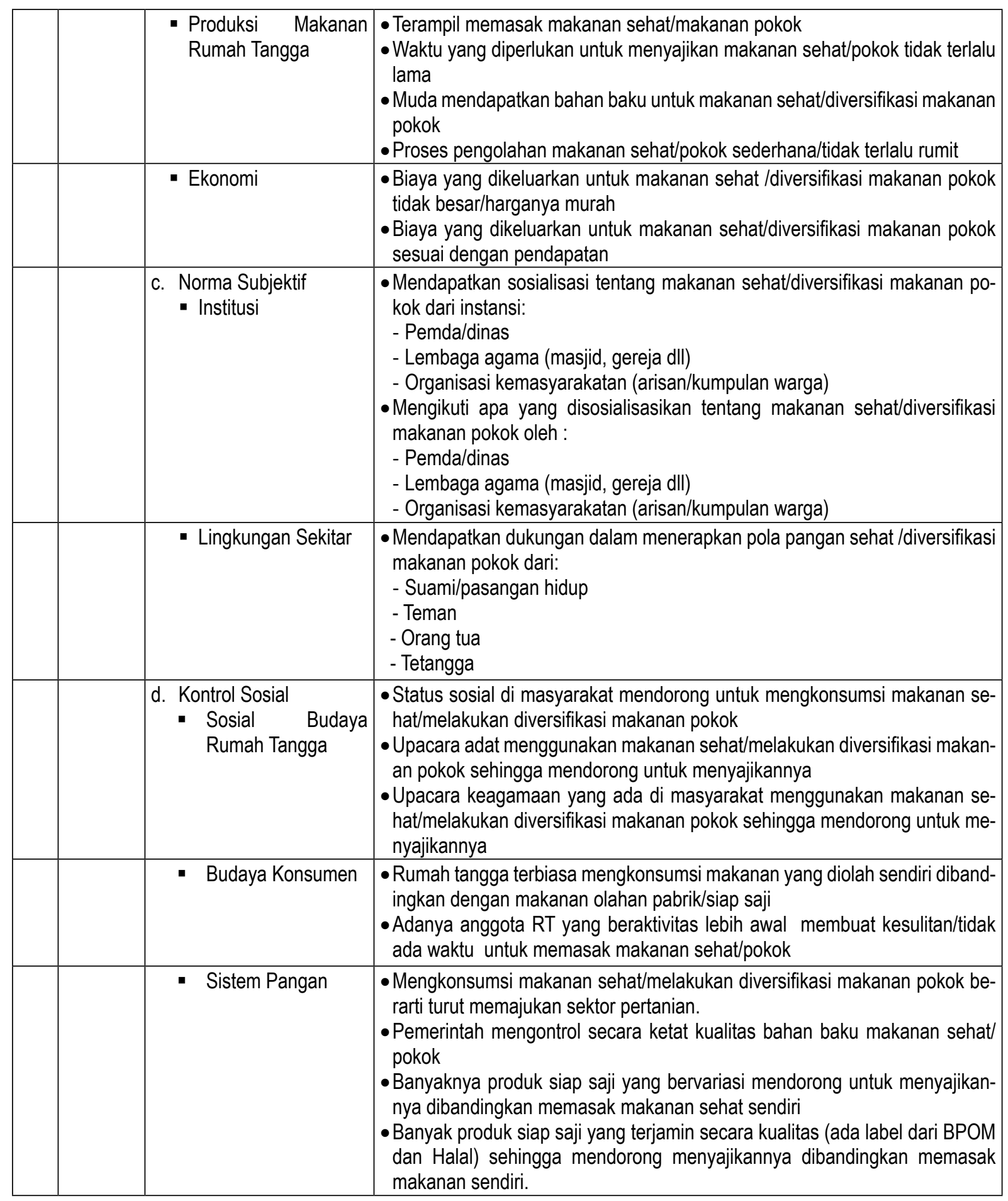

\section{HASIL DAN PEMBAHASAN}

\section{Perilaku Konsumsi Pangan Masyarakat di DIY}

Pada umumnya rumah tangga yang menjadi responden di DIY telah mengkonsumsi pangan sehat yaitu makanan yang beragam jenisnya, bergizi, seimbang dan aman dikonsumsi. Hal tersebut dapat dilihat dari 199 responden RT, sekitar $79 \%$ sering dan sangat sering mengkonsumsi makanan sehat, artinya sekurangnya 4 hari dalam seminggu mereka mengkonsumsi pangan sehat. Hanya sekitar $12,8 \%$ responden yang jarang dan $8 \%$ pernah, mereka hanya sesekali dalam seminggu mengkonsumsi makanan sehat (lihat Gambar 6).

Pemahaman ibu rumah tangga yang menjadi responden terhadap makanan sehat cukup baik. Sebagian besar yaitu 97,03\% responden mengetahui konsep 4 sehat 5 sempurna sebagai makanan sehat, namun yang paham tentang 


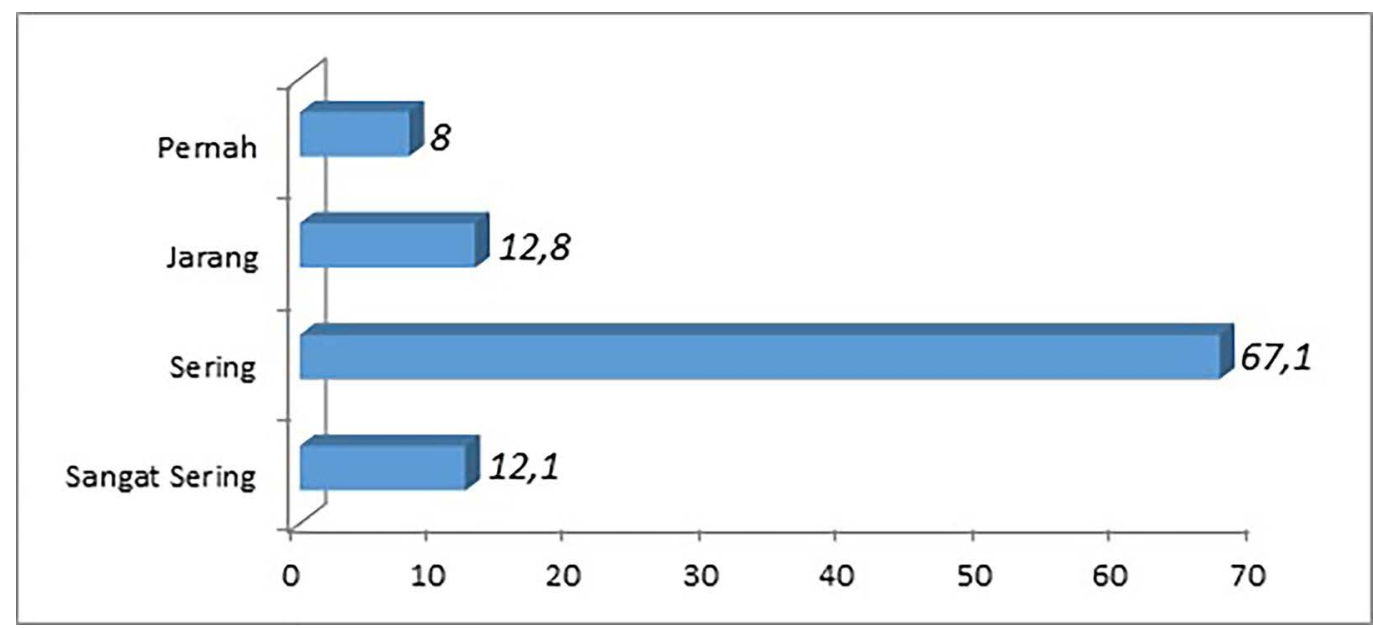

Sumber: Data Primer, 2015 (diolah)

Gambar 6. Responden yang Mengkonsumsi Makanan sehat di DI Yogyakarta

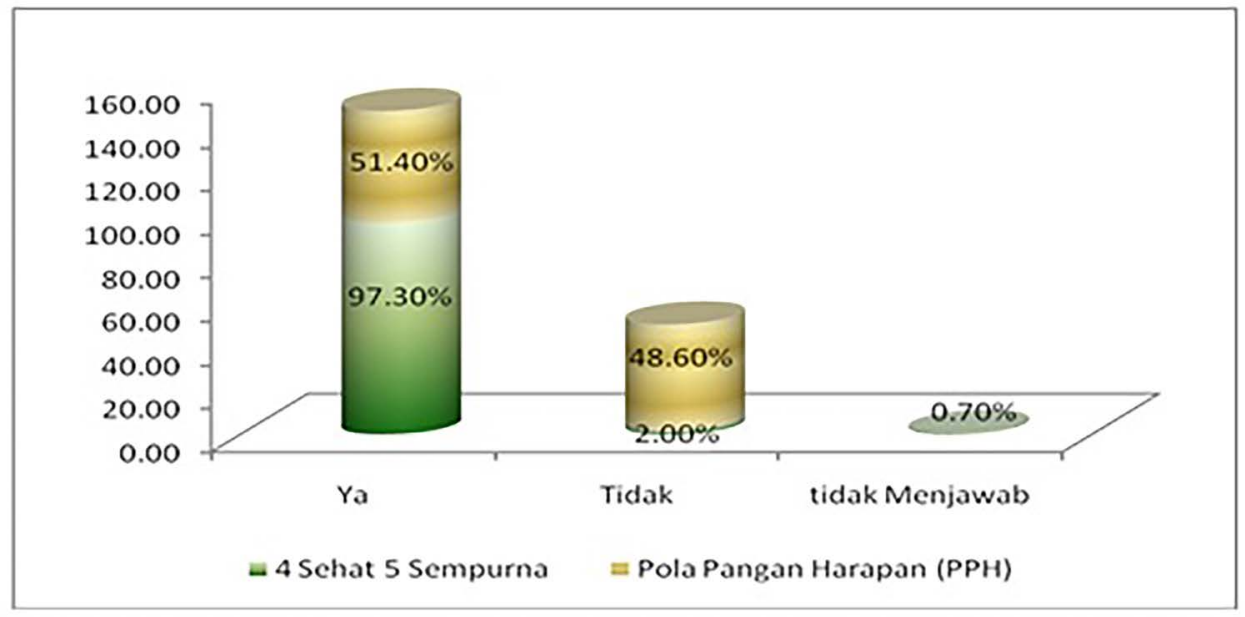

Sumber: Data Primer, 2015 (diolah)

Gambar 7. Responden yang Mengkonsumsi Makanan sehat di DI Yogyakarta

pola pangan harapan baru sekitar $51,40 \%$ (lihat Gambar 6) . Artinya bahwa ada separuh IRT yang menjadi responden belum mengerti bahkan belum mendengar konsep PPH. Ini mengindikasikan bahwa pemerintah perlu meningkatkan sosialisasi tentang konsep PPH kepada masyarakat sehingga masyarakat paham bahwa makanan sehat tidak hanya sebatas pada kuantitas tetapi kualitas, selain keberagaman makanan, perlu porsi yang tepat dari setiap jenis makanan yang dikonsumsi sehingga pola pangan harapan yang ideal dapat tercapai.

Di DIY, banyak faktor yang memengaruhi pola perilaku RT dalam mengkonsumsi makanan. Berdasarkan hasil analisis jalur dengan model trimming (lihat Tabel 2 dan Gambar 8) menunjukkan bahwa perilaku konsumsi makanan sehat tersebut sangat dipengaruhi oleh keinginan atau intensi seorang ibu rumah tangga untuk menyajikan makanan sehat setiap harinya untuk keluarga. Intensi IRT berpengaruh langsung dan signifikan terhadap perilaku konsumsi makanan sehat sebesar 0,513 atau 51,3\%. Besarnya koefisien keinginan IRT tersebut karena umumnya para ibu di DIY memiliki peran yang signifikan dalam memegang kendali urusan dapur termasuk menentukan menu makanan sehat yang akan dikonsumsi untuk keluarganya dibandingkan dengan anggota keluarga lainnya seperti bapak atau anak. Seperti yang dituturkan salah satu narasumber IRT di DIY (2015) yang mengatakan bahwa:"....biasanya saya langsung saja menyediakan makanan untuk anak-anak dan 
Tabel 2. Korelasi Antara Faktor Yang Memengaruhi Prilaku Konsumsi Pangan di DIY

\begin{tabular}{cccccc} 
& $X_{1}$ & $X_{2}$ & $X_{3}$ & $X_{4}$ & $X_{5}$ \\
$X_{1}$ & 1 & $0,716^{* *}$ & $0,270^{* *}$ & $0,434^{* *}$ & $0,0197^{*}$ \\
$X_{2}$ & $0,716^{* *}$ & 1 & $0,326^{* *}$ & $0,483^{* *}$ & $0,162^{*}$ \\
$X_{3}$ & $0,270^{* *}$ & $0,326^{* *}$ & 1 & $0,307^{* *}$ & $0,255^{* *}$ \\
$X_{4}$ & $0,434^{* *}$ & $0,482^{* *}$ & $0,307^{* *}$ & 1 & $0,258^{* *}$ \\
$X_{5}$ & $0,197^{*}$ & $0,162^{*}$ & $0,255^{* *}$ & $0,258^{* *}$ & 1 \\
\hline
\end{tabular}

Sumber: Data Primer 2015 (diolah)

Keterangan: $\left.{ }^{* *}\right)$ Korelasi signifikan pada tingkat $5 \%(0,05)$

*) Korelasi signifikan pada tingkat $10 \%(0,10)$

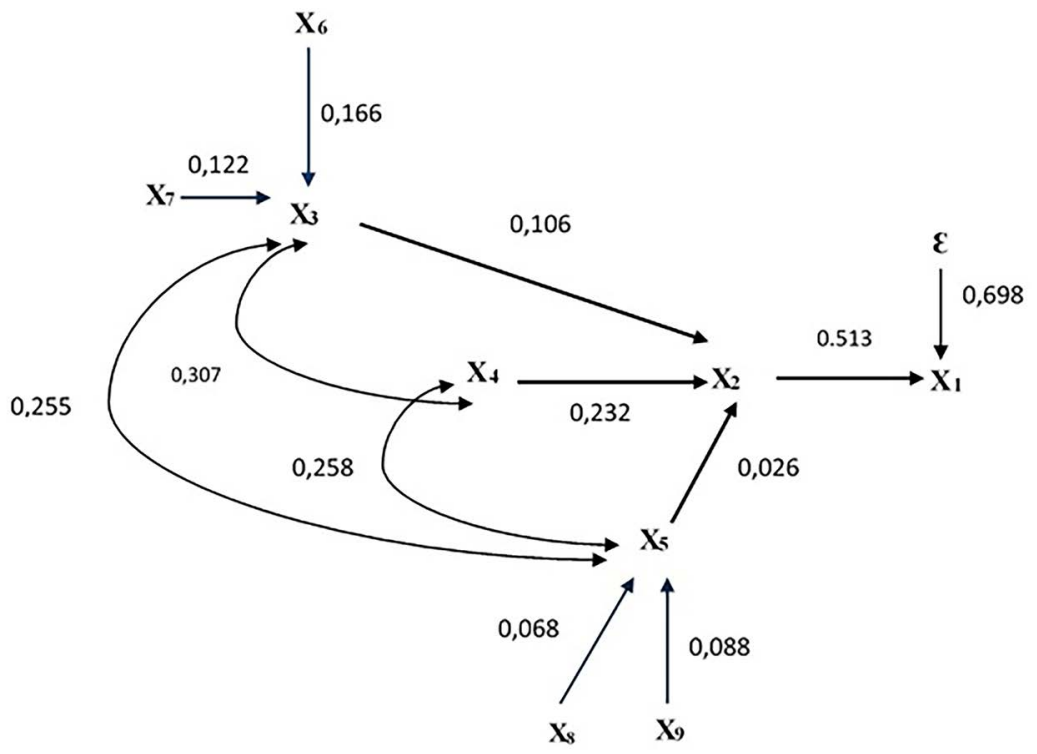

Sumber: Data Primer, 2015 (diolah)

Keterangan:

$\mathbf{X}_{\mathbf{1}}=$ Perilaku Keluarga dalam mengkonsumsi makanan sehat

$\mathbf{X}_{2}=$ Intensi menyajikan konsumsi makanan sehat untuk keluarga

$\mathbf{X}_{\mathbf{3}}=$ Makanan yang sehat sangat penting untuk dikonsumsi oleh keluarga

$\mathbf{X}_{4}=$ Dukungan suami untuk menyajikan makanan sehat

$\mathbf{X}_{\mathbf{5}}=$ Kontrol Lingkungan dalam menyajikan makanan sehat

$\mathbf{X}_{6}=$ Makanan sehat membuat tubuh selalu sehat/jarang sakit

$\mathbf{X}_{7}=$ Makanan sehat mampu memenuhi kebutuhan gizi tubuh

$\mathbf{X}_{\mathbf{8}}=$ Keluarga lebih terbiasa mengkonsumsi makanan olahan sendiri

dibandingkan makanan instan/siap saji

$\mathbf{X}_{\mathbf{9}}=$ Mengkonsumsi makanan sehat berarti turut memajukan sektor pertanian di dalam negeri.

Gambar 8. Hubungan Struktural Faktor-faktor yang Memengaruhi Konsumsi Makanan Sehat di DIY

suami, menunya tergantung saya, yang penting sudah saya siapkan makanan untuk mereka. Mereka (bapak dan anak) biasanya memakan apa saja yang saya siapkan di meja makan...".

Keinginan IRT di DIY dalam menyajikan pangan sehat untuk keluarga dipengaruhi oleh sikap IRT yang memandang bahwa makanan sehat sangat penting untuk dikonsumsi oleh keluarga, dukungan suami, dan kontrol lingkungan yang ada di masyarakat (lihat Gambar 11). Sikap (ibu rumah tangga) yang menganggap bahwa penting mengkonsumsi makanan sehat bagi 


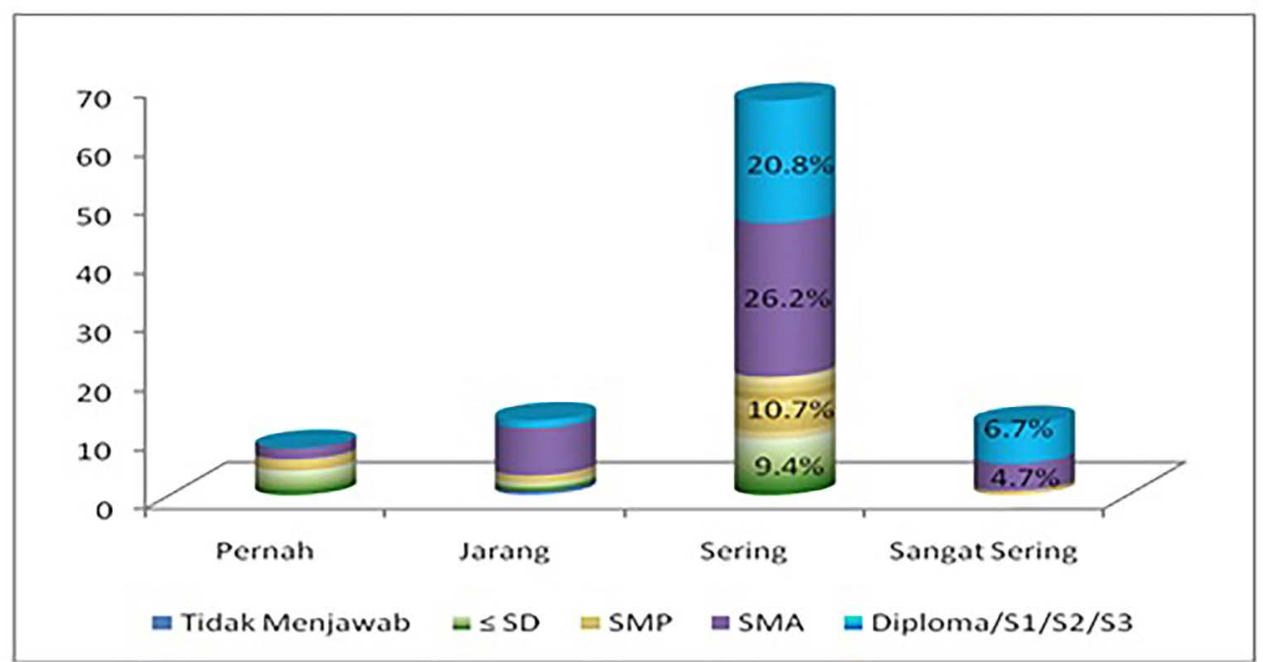

Sumber: Data Primer, 2015 (diolah)

Gambar 9. Responden yang Mengkonsumsi Makanan sehat Berdasarkan Tingkat Pendidikan IRT di DI Yogjakarta

keluarga berpengaruh secara langsung dan signifikan sebesar 0,106 atau 10,6\% terhadap keinginan untuk menyajikan makanan sehat. Di DIY, sikap tersebut secara signifikan sebesar 0,122 atau $12,2 \%$ dipengaruhi oleh pemahaman dan pengalaman bahwa makanan sehat ketika dikonsumsi akan mampu memenuhi kebutuhan gizi yang diperlukan oleh tubuh serta membuat tubuh selalu sehat dan jarang sakit berpengaruh sebesar 0,166 atau $16,66 \%$ terhadap sikap IRT (lihat Gambar 8). Hal tersebut diperkuat oleh pernyataan narasumber kelompok wanita tani (KWT) Anggrek di Gunung Kidul DIY (2015) yang mengatakan bahwa:"... dahulu nenek-nenek kita tetap sehat meskipun usianya sudah lanjut, berbeda dengan sekarang yang usia segini saja sudah sering sakit, penyebabnya adalah pola makan. Nenek kita dahulu mengkonsumsi makanan sehat yang bebas dari zat-zat kimia...".

Pada umumnya, rumah tangga yang mengkonsumsi makanan sehat memiliki IRT dengan pengetahuan dan tingkat pendidikan yang cukup. Hal tersebut dapat dilihat dari Gambar 9, bahwa rumah tangga dengan ibu yang berpendidikan SMA ke atas lebih sering mengkonsumsi makanan sehat. Dari 67,1\% responden yang sering mengkonsumsi makanan sehat, sebanyak $70,04 \%$ IRT nya berpendidikan SMA dan diploma/S1/S2/S3. Sementara RT yang sangat sering atau setiap hari mengkonsumsi makanan sehat sebanyak $18 \%$, dan $63,33 \%$ IRT nya berpendidikan SMA serta diploma/S1/S2/S3.

Dengan pengetahuan yang dimiliki, para ibu dapat memilih mana makanan yang baik dan sehat untuk dikonsumsi oleh keluarganya dan berpikir bagaimana mendapatkan makanan sehat tersebut tanpa harus tergantung terhadap besar kecilnya pendapatan. Biasanya para ibu di DIY terutama di perdesaan menanam sayuran seperti bayam, kangkung, tomat, labu siam, gambas atau oyong di pekarangan rumahnya untuk memenuhi kebutuhan makanan sayur-sayuran. Selain itu, ada juga yang memelihara ayam dan lele terutama ibu rumah tangga (IRT) yang mendapat bantuan dari program Kawasan Rumah Pangan Lestari (KRPL) sehingga kebutuhan serat dan protein keluarga tercukupi, meskipun pendapatan keluarga tidak besar. Sebagaimana dinyatakan oleh IRT yang menjadi narasumber di kabupaten Gunung Kidul (2015), bahwa dengan menanam sayuran serta memelihara ayam di pekarangan rumah, konsumsi makanan sehat dapat dilakukan dengan mudah dan murah. Banyak kegiatan yang dilakukan dalam program KRPL, di DIY salah satunya adalah dengan menanam holtikultura yang dimasukan dalam polibag dengan memanfaatkan pekarangan rumah, ternak unggas, budidaya lele, dan lain sebagainya.

Dengan adanya program KRPL, para IRT di salah satu kabupaten Gunung Kidul, tidak lagi tergantung pada pendapatan suami untuk 
bisa memenuhi kebutuhan gizi keluarganya. Bahkan salah satu anggota kelompok wanita tani (KWT) yang mendapatkan program KRPL mengakui bahwa selain tidak terlalu tergantung pada pendapatan suami, mereka juga mampu mendapatkan penghasilan dengan menjual sayuran, ikan lele, dan ternak (ayam) yang berlebih dari hasil program KRPL. Hal tersebut diperkuat sebagaimana dalam Tabel 3 bahwa bukan hanya responden yang berpendapatan lebih dari 5 juta yang sering dan sangat sering mengkonsumsi makanan sehat di DIY, bahkan justru sebanyak $24,3 \%$ responden yang sering mengkonsumi makanan sehat memiliki pendapatan antara Rp 1,1 sampai 3 juta, dan 16,9\% responden yang mengkonumsi makanan sehat memiliki pendapatan rumah tangga kurang dari Rp 1 juta.

Tabel 3. Konsumsi Makanan Sehat Berdasarkan Tingkat Pendapatan di DI.Yogyakarta

\begin{tabular}{|c|c|c|c|c|}
\hline & $\begin{array}{c}\leq \text { Rp } 1 \\
\text { Juta }\end{array}$ & $\begin{array}{c}\text { Rp 1,1 -3 } \\
\text { Juta }\end{array}$ & $\begin{array}{c}\text { Rp 3,1 - } 5 \\
\text { Juta }\end{array}$ & $\begin{array}{c}\text { Rp }>5 \\
\text { Juta }\end{array}$ \\
\hline $\begin{array}{l}\text { Sangat } \\
\text { Sering }\end{array}$ & $0,7 \%$ & $4,7 \%$ & $8,1 \%$ & $7,4 \%$ \\
\hline Sering & $16,9 \%$ & $24,3 \%$ & $8,8 \%$ & $10,1 \%$ \\
\hline Jarang & $4,1 \%$ & $1,4 \%$ & $0,7 \%$ & -- \\
\hline Pernah & $6,1 \%$ & $3,4 \%$ & $0,7 \%$ & -- \\
\hline $\begin{array}{l}\text { Tidak } \\
\text { Pernah }\end{array}$ & --- & $0,7 \%$ & $1,4 \%$ & $0,7 \%$ \\
\hline Total & $27,7 \%$ & $34,5 \%$ & $19,6 \%$ & $18,2 \%$ \\
\hline
\end{tabular}

Sumber: Data Primer, 2015 (diolah)

Dengan kondisi tersebut di atas maka di DIY, faktor ekonomi seperti pendapatan dan biaya tidak berpengaruh secara signifikan terhadap sikap untuk konsumsi makan sehat, begitupun dengan ketersediaan bahan baku karena RT mudah untuk mendapatkan pangan pokok terutama sayur dan sumber protein dan karbohidrat. Sementara untuk proses pengolahan, para IRT di DIY memiliki keterampilan sangat memadai yang didapat dari keluarga sehingga tidak mengalami kesulitan dalam menyajikan makanan sehat serta memiliki waktu yang cukup longgar untuk mengolah makanan sehat karena pada umumnya mereka tidak bekerja di luar rumah. Dengan demikian, dengan model trimming, variabel-variabel sikap yang tidak signifikan tidak masuk dalam model. Hanya pemahaman bahwa konsumsi makanan sehat penting untuk keluarga karena dapat membuat tubuh menjadi jarang sakit/sehat dan dapat memenuhi kebutuhan gizi tubuh yang berpengaruh secara signifikan terhadap intense IRT menyajikan makanan sehat (lihat Gambar 8).

Sementara itu untuk norma subjektif, variabel yang berpengaruh secara langsung dan signifikan terhadap intensi IRT dalam menyajikan makanan sehat yakni variabel dukungan suami dengan persentase sebesar 23,2\%. Sebanyak 89,12\% responden sering dan sangat sering mendapat dukungan dari suami, hal tersebut diakui oleh salah satu ibu yang menjadi narasumber di kabupaten Gunung Kidung DIY (2015) yang menyatakan bahwa dukungan yang diberikan oleh suami sebagai orang terdekat menjadi motivasi terbesar dalam menyajikan makanan sehat. Dukungan yang diberikan suami biasanya dalam bentuk pujian kepada istri atau perilaku menghabiskan makanan yang disajikan oleh para ibu.

Terkait dengan faktor lain seperti sosialisasi tentang makanan sehat atau pola pangan harapan (PPH) baik dari dinas/pemda, lembaga keagamaan maupun organisasi kemasyarakatan (arisan/kumpulan warga), tidak berpengaruh secara signifikan terhadap niat responden untuk menyajikan makanan sehat. Kondisi ini dapat dipahami mengingat sebagian besar responden tidak pernah sampai jarang mendapatkan sosialisasi tentang PPH, hanya sebagian kecil yang mendapatkan sosialisasi baik dari dinas/ pemda, lembaga keagamaan maupun organisai kemasyarakatan (lihat Gambar 10). Petugas dari dinas mensosialisasikan PPH hanya pada waktu jam kerja, belum terinternalisasi untuk mensosialisaikan PPH di setiap kesempatan di luar jam kerja.

Sosialisasi PPH lebih sering responden dapatkan dari organisasi kemasyarakatan pada waktu arisan maupun kumpulan warga baik di tingkat RT maupun RW. Anjuran sosialisasi yang dilakukan oleh lembaga-lembaga kemasyarakatan tersebut lebih sering diikuti dan dilaksanakan oleh responden dibandingkan dengan yang dilakukan oleh dinas/pemda dan lembaga keagamaaan. Hal tersebut dapat dilihat di Gambar 11, dimana ada lebih dari $41,6 \%$ responden yang selalu melaksanakan apa yang dianjurkan oleh organisasi kemasyarakatan, sementara yang dilakukan oleh dinas/pemda diikuti oleh $30 \%$ 


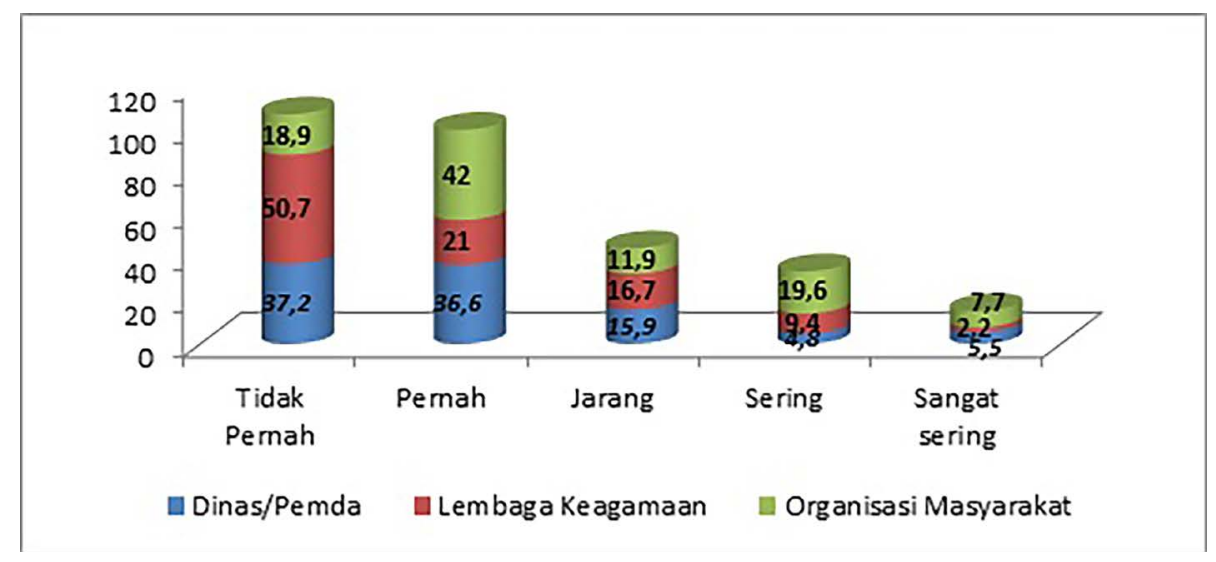

Sumber: Data Primer, 2015 (diolah)

Gambar 10. Responden Mendapatkan Sosialisasi Pola Pangan Harapan (PPH) dari Dinas/Pemda, Lembaga Keagamaan, dan Organisasi Kemasyarakatan di DIY (\%)

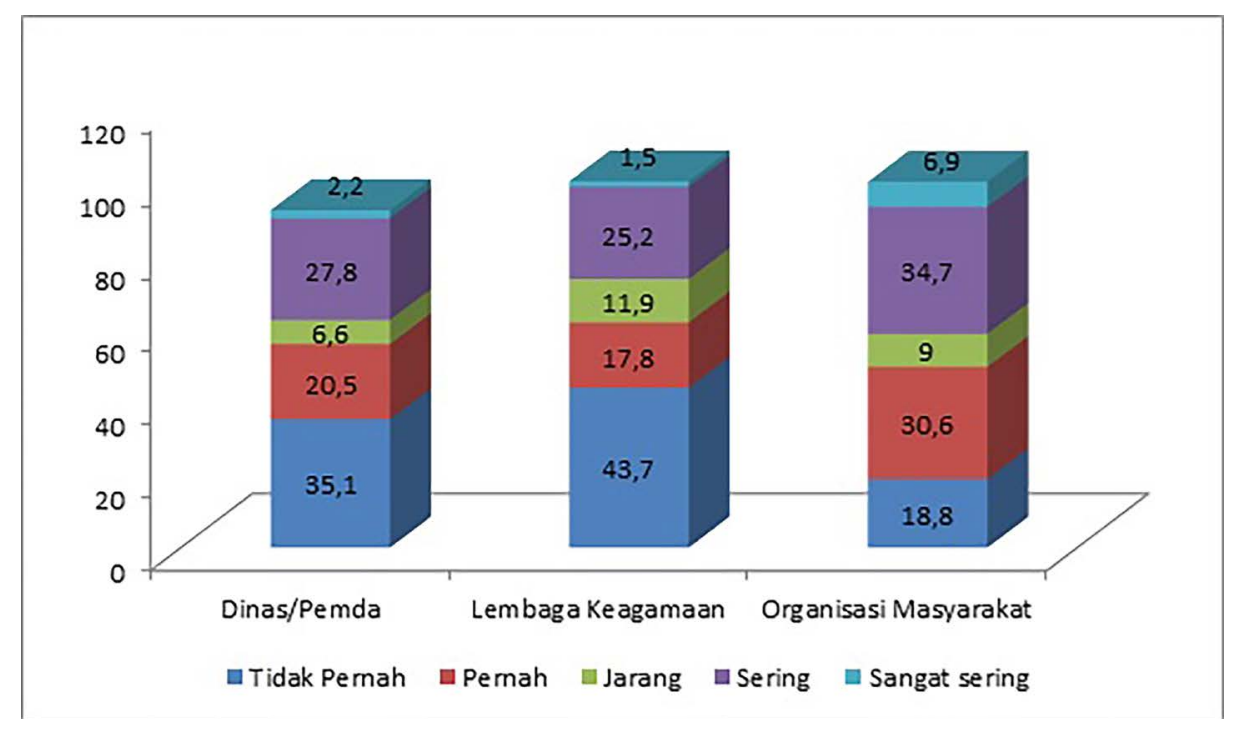

Sumber: Data Primer 2015 (diolah)

Gambar 11. Responden Mengikuti Anjuran Sosialisasi Pola Pangan Harapan (PPH) dari Dinas/Pemda, Lembaga Keagamaan, dan Organisasi Kemasyarakatan di DIY(\%)

responden dan lembaga kegamaan diikuti oleh sekitar 26,5\% responden. Dengan demikian, cara efektif melakukan sosialisasi PPH agar berpengaruh terhadap intensi dan perilaku responden dalam menyajikan makanan sehat adalah dengan meningkatkan frekuensi sosialisasi melalui organisasi kemasyarakatan yang ada.

Sementara untuk kontrol perilaku, lingkungan berpengaruh secara signifikan sebesar 0,026 atau $2,6 \%$ terhadap niat menyajikan makanan sehat. Lingkungan yang berpengaruh tersebut kebiasaaan di keluarga yang lebih terbiasa mengkonsumsi makanan olahan sendiri dibandingkan dengan mengkonsumsi makanan instan/siap saji serta responden menganggap dengan mengkonsumsi makanan sehat berarti memajukan sektor pertanian di wilayahnya, karena bahan baku didapatkan dari daerah sendiri, tidak perlu mengimpor.

Upacara adat dan keagamaan tidak berpengaruh secara signifikan terhadap kontrol lingkungan dalam menyajikan makanan sehat, meskipun di beberapa upacara keagamaan maupun adat sebagian responden terdorong untuk menyajikan makanan sehat. 


\section{Perilaku Konsumsi Pangan Pokok Non Beras Masyarakat di NTT}

Perilaku konsumsi pangan pokok keluarga di NTT masih di dominasi oleh beras. Hal tersebut dapat di lihat dari Gambar 4.12, dimana sebagian besar responden yaitu 56,3\% mengkonsumsi pangan pokok non beras kurang dari 3 hari selama seminggu dan $6,5 \%$ responden selalu mengkonsumsi pangan pokok beras setiap harinya. Konsumsi pangan pokok non beras lebih dari 4 hari dalam seminggu dilakukan oleh $34,2 \%$ responden dan hanya $3 \%$ responden yang hampir setiap hari mengkonsumsi makanan pokok non beras seperti jagung dan umbi-umbian.

Makanan pokok non beras lebih banyak dikonsumsi oleh responden yang tinggal di pedesaan dibandingkan dengan perkotaan. Di Kota Kupang, sebanyak 49,2\% responden mengkonsumsi beras sebagai makanan pokok, sementara di kabupaten TTS berimbang antara responden yang menyajikan beras $(29,6 \%)$ dan non beras $(20,6 \%)$ sebagai makanan pokok. Responden yang menyajikan beras sebagai makanan pokok untuk keluarganya sebagian besar berpendidikan diploma dan sarjana, sementara yang menyajikan nasi jagung sebagian berpendidikan SMP (17,1\%). Kondisi ini merupakan hal yang ironi mengingat seharusnya semakin tinggi tingkat pendidikan maka akan semakin terdiversifikasi dan berimbang jenis makanan pokok yang di sajikan dan konsumsi oleh keluarganya (lihat Gambar 13).
Banyak faktor yang memengaruhi konsumsi pangan non beras di NTT. Faktor utama yang berpengaruh terhadap perilaku konsumsi pangan non beras di keluarga adalah niat ibu untuk untuk menyajikan makanan pokok non beras tersebut, sedangkan niat sendiri dipengaruhi oleh sikap serta kontrol lingkungan (lihat Gambar 14 dan tabel 4.). Berdasarkan hasil analisis jalur, niat berpengaruh langsung dan signifikan sebesar 0,361 atau 36,1\% terhadap perilaku konsumsi pangan non beras di keluarga. Hal tersebut tidak mengherankan karena $80 \%$ ibu yang menjadi responden memiliki kewenangan mutlak menentukan jenis makanan pokok yang akan dikonsumsi oleh keluarganya. Hingga sasaran program yang dijalankan oleh BKPP adalah kalangan ibu rumah tangga dan kader PKK. Hal ini karena secara umum, ibu-ibu memainkan peran penting dalam memutuskan pangan apa yang akan dikonsumi oleh keluarga.

Tabel 4. Korelasi Antara Faktor Yang Memengaruhi Prilaku Konsumsi Pangan Pokok Non Beras di NTT

\begin{tabular}{|c|cccc|} 
& $\mathbf{Y}_{1}$ & $\mathbf{Y}_{2}$ & $\mathbf{Y}_{3}$ & $\mathbf{Y}_{4}$ \\
\hline $\mathbf{Y}_{1}$ & 1 & $0,601^{* *}$ & $0,197^{* *}$ & $0,282^{* *}$ \\
\hline $\mathbf{Y}_{2}$ & $0,601^{* *}$ & 1 & $0,205^{* *}$ & $0,226^{* *}$ \\
$\mathbf{Y}_{3}$ & $0,197^{* *}$ & $0,205^{* *}$ & 1 & 0,084 \\
$\mathbf{Y}_{4}$ & $0,282^{* *}$ & $0,226^{* *}$ & 0,084 & 1 \\
\hline
\end{tabular}

Sumber: Data Primer 2015 (diolah)

Keterangan: **) Korelasi signifikan pada tingkat 5\%(0,05)

*) Korelasi signifikan pada tingkat $10 \%(0,10)$

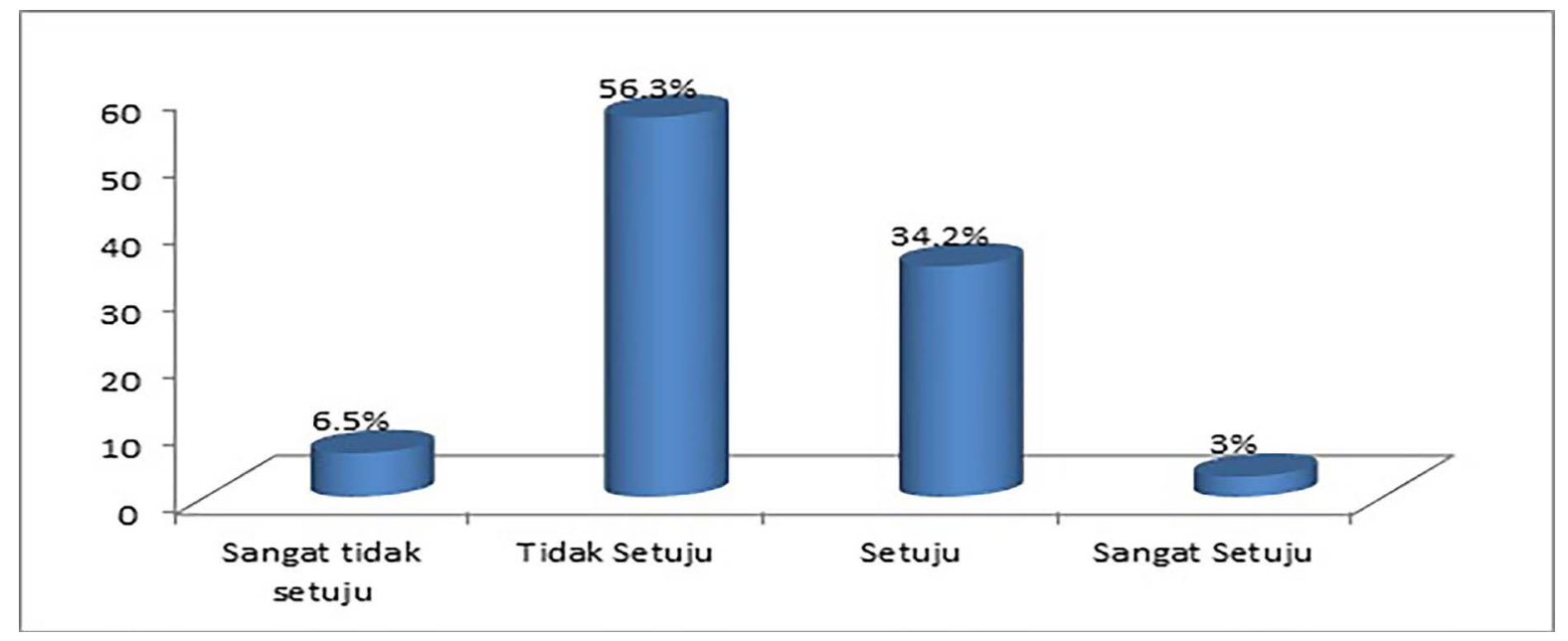

Sumber: Data Primer, 2015 (diolah)

Gambar 12. Responden Mengkonsumsi Makanan Pokok Non Beras Setiap Hari di NTT 

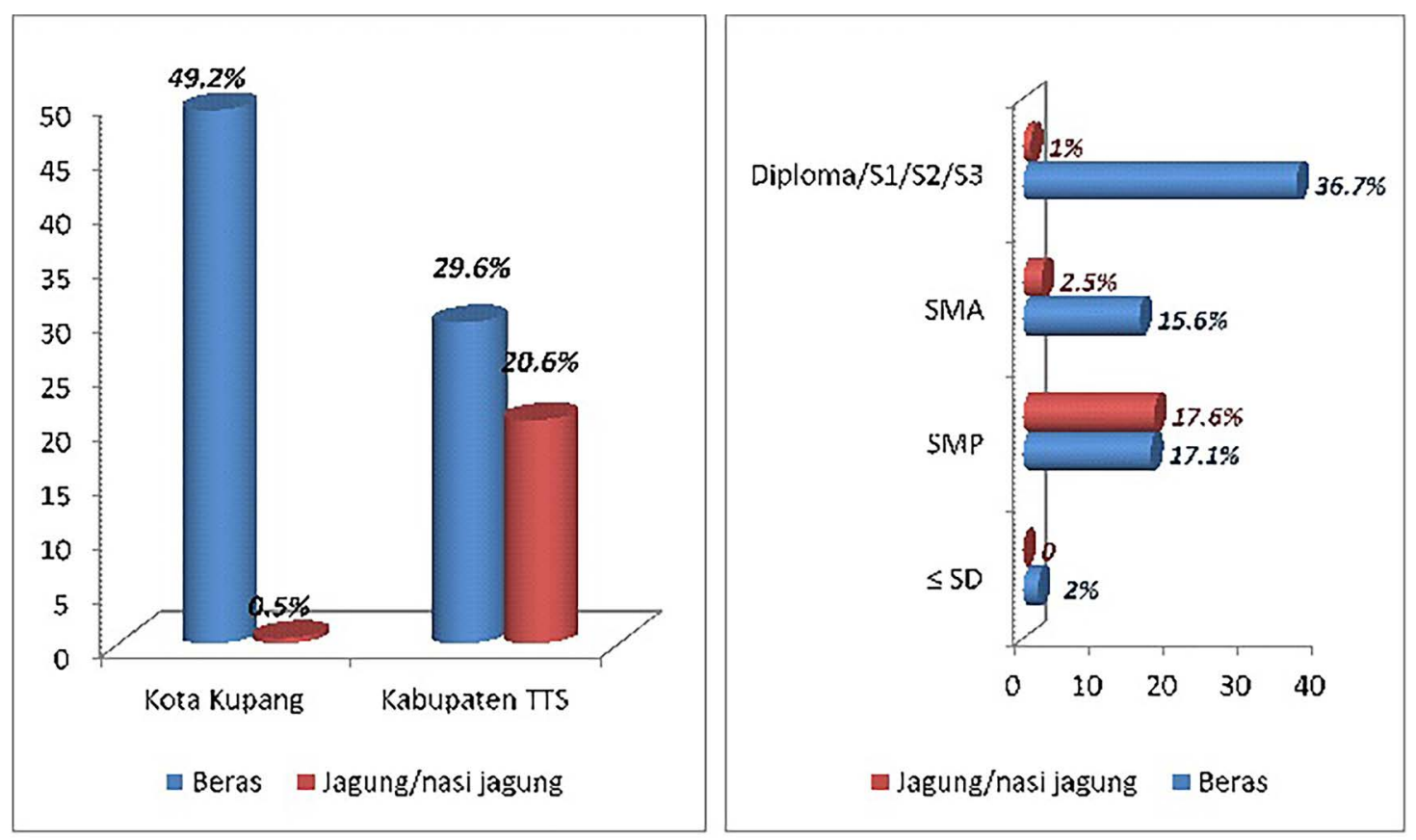

Sumber : Data Primer, 2015 (diolah)

Gambar 13. Responden Mengkonsumsi Makanan Pokok Non Beras Setiap Hari di NTT

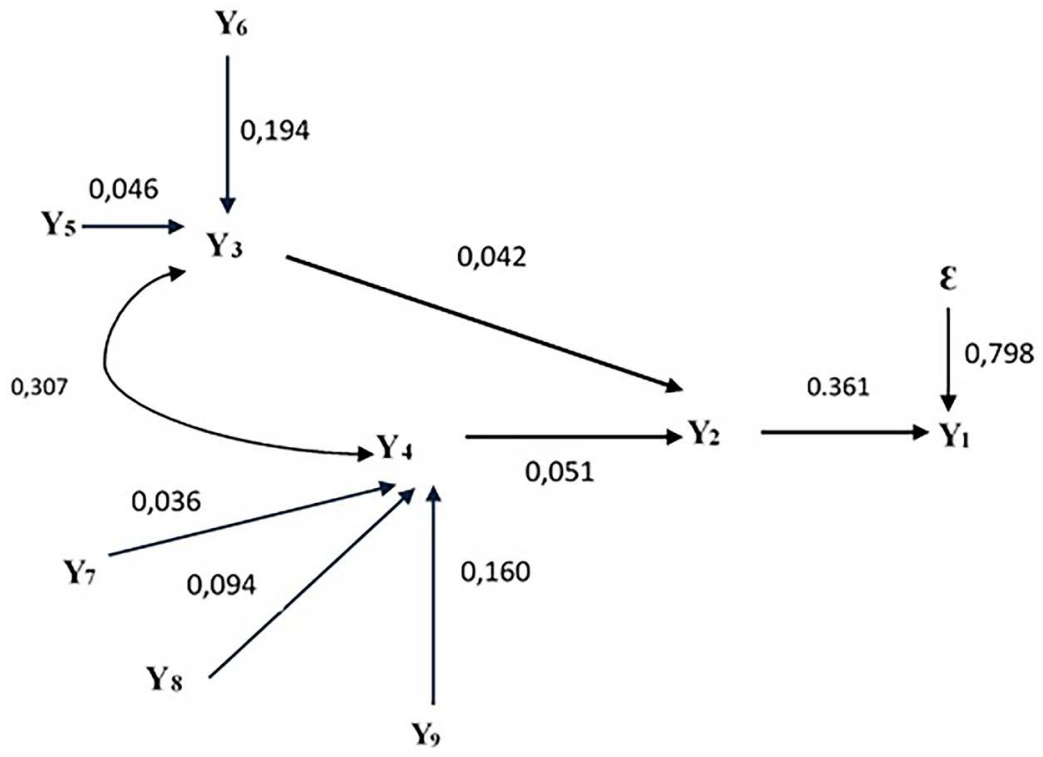

Sumber : Data Primer, 2015 (diolah)

Keterangan:

$\mathrm{Y}_{1}=$ Perilaku Keluarga dalam mengkonsumsi makanan pokok non beras

$\mathrm{Y}_{2}=$ Niat menyajikan konsumsi makanan pokok non beras untuk keluarga

$\mathrm{Y}_{3}=$ Penting mengkonsumsi makanan pokok non beras (sikap)

$\mathrm{Y}_{6}=$ Mengkonsumsi makanan pokok non beras membuat tubuh sehat/jarang sakit

$\mathrm{Y}_{5}=$ Terampil memasak makanan pokok non beras

$\mathrm{Y}_{4}=$ Kontrol Lingkungan dalam menyajikan makanan pokok non beras

$\mathrm{Y}_{7}=$ Mengkonsumsi makanan pokok non beras dimanapun berada

$\mathrm{Y}_{8}=$ Terbiasa mengkonsumsi makanan olahan sendiri dibandingkan makanan instan/siap saji

$\mathrm{Y}_{9}=$ Upacara Keagamaan

Gambar 14. Hubungan Struktural Faktor-faktor yang Memepengaruhi Konsumsi Pangan Pokok Non Beras di NTT 


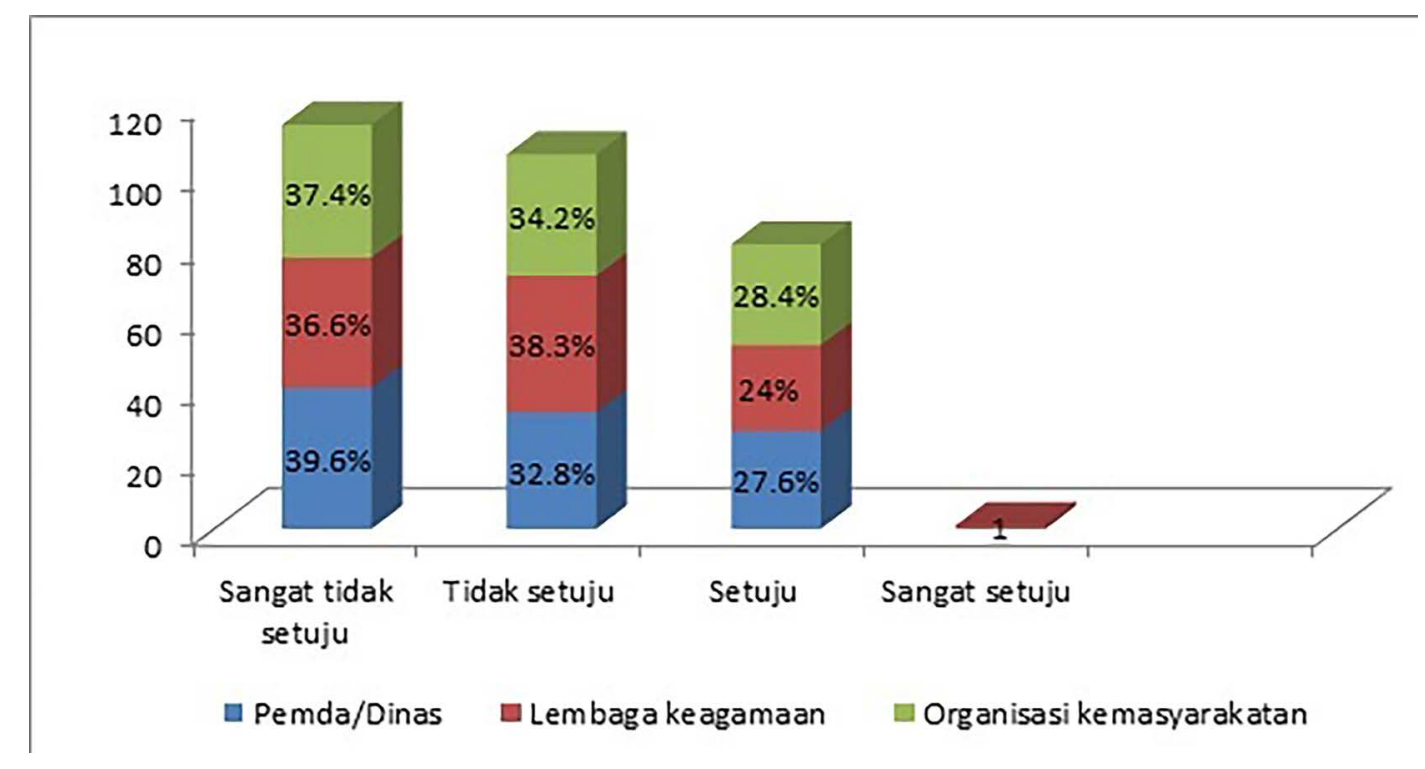

Sumber: Data Primer, 2015 (diolah)

Gambar 15. Responden Mendapatkan Sosialisasi Penganekaragaman Makanan Pokok dari Dinas/Pemda, Lembaga Keagamaan, dan Organisasi Kemasyarakatan di NTT (\%)

Sementara itu, sikap berpengaruh signifikan sebesar 0,042 atau 4,2\% terhadap niat ibu dalam menyajikan makanan pokok non beras untuk keluarganya. Ibu yang menjadi responden memandang penting menyajikan makanan pokok non beras karena mengkonsumsi makanan pokok non beras membuat tubuh menjadi selalu sehat/ jarang sakit. Selain itu, responden terampil dalam mengolah/memasak makanan pokok non beras sehingga anggota keluarga tidak bosan dalam mengkonsumsinya.

Faktor penentu sikap lainnya seperti ketersediaan bahan baku, biaya, waktu yang dibutuhkan untuk mengolah pangan pokok non beras tidak memiliki pengaruh terhadap sikap responden dalam menyajikan makanan pokok non beras. Bagi responden, faktor-faktor tersebut bukan merupakan pertimbangan utama dalam menentukan sikap.

Norma subjektif seperti sosialisasi tentang penganekaragaman makanan pokok baik dari dinas/pemda, lembaga keagamaan maupun organisasi sosial, serta dukungan dari suami dan orang tua tidak berpengaruh secara signifikan terhadap niat responden untuk menyajikan makanan pokok yang beranekaragam. Tidak adanya pengaruh sosialisasi terhadap niat mengkonsumsi makanan pokok yang beraneka ragam diduga karena selama ini sebagian besar responden tidak mendapatkan sosialisasi baik dari pemda/dinas, lembaga keagamaan maupun organisasi kemasyarakatan, hanya sekitar 24$28,4 \%$ responden yang mendapatkan sosialiasasi mengenai penganekaragaman makanan pokok (lihat Gambar 15).

Dalam sosialisasi penganekaragaman makanan pokok kadang anjurannya tidak diikuti oleh para responden (lihat Gambar 16). Dari Gambar 16, terlihat bahwa responden cenderung mengikuti apa yang dianjurkan oleh LSM sebanyak 52,8\% (33,2\% setuju dan 19,6\% sangat setuju) dibandingkan dengan organisasi kemasyarakatan (37,1\%), lembaga keagamaan $(31,7 \%)$, dan dinas/pemda (36,8\%). Banyaknya LSM yang masuk di NTT untuk memberi bantuan kepada masyarakat membuat hubungan antara masyarakat dengan LSM menjadi erat dan menumbuhkan kepercayaan terhadap LSM sehingga masyarakat lebih mudah untuk mengikuti anjuran LSM dibandingan dengan yang lain. Hal ini merupakan pekerjaan rumah bagi pemerintah atau dinas setempat, bagaimana membuat masyarakat untuk lebih percaya dan mengikuti anjuran Dinas dibandingkan dari stakeholders lainnya.

Sementara faktor lingkungan berpengaruh sebesar 0,051 atau 5,1\% terhadap niat responden untuk menyajikan makanan pokok yang beraneka 


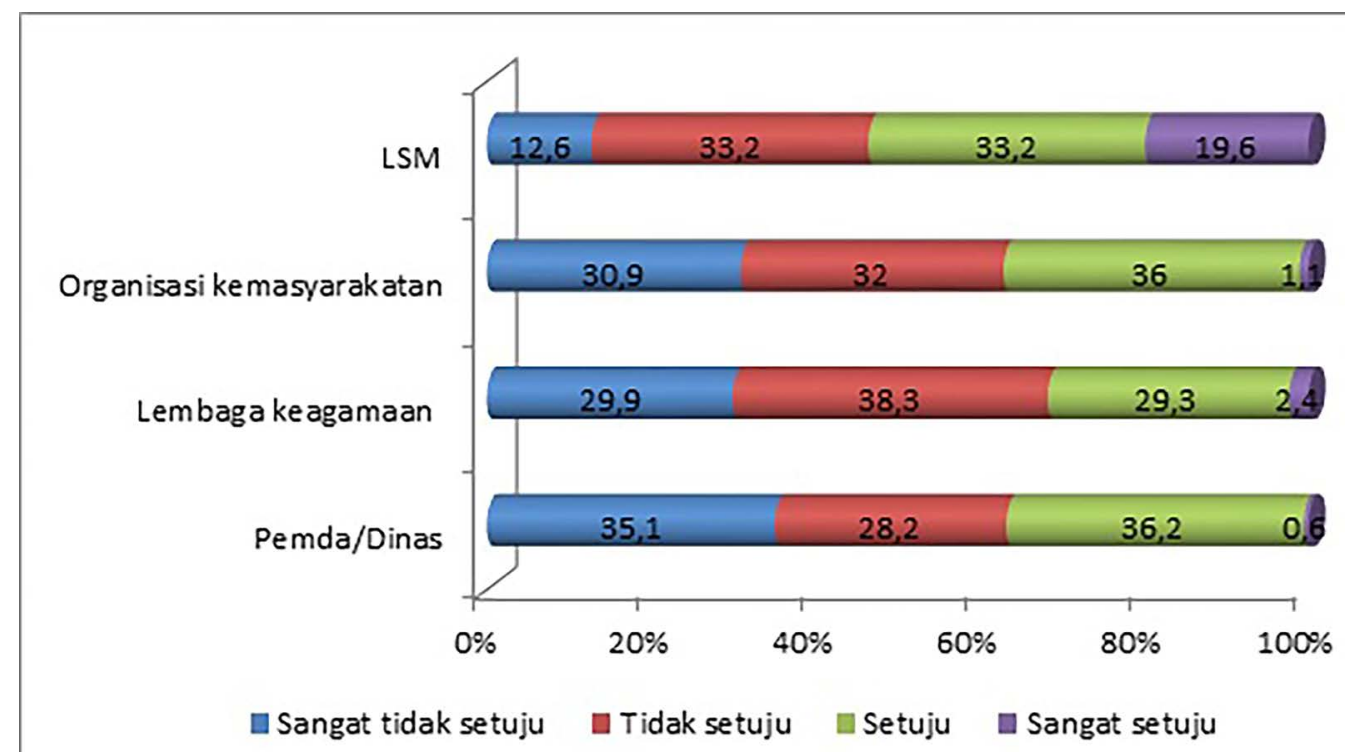

Sumber : Data Primer, 2015 (diolah)

Gambar 16. Responden Mengikuti Anjuran Sosialisasi Pola Pangan Harapan (PPH) dari Dinas/Pemda, Lembaga Keagamaan, Organisasi Kemasyarakatan, dan LSM di NTT (\%)

ragam. Faktor lingkungan tersebut dipengaruhi oleh kebiasaan mengkonsumsi makanan pokok non beras dibandingakan dengan makanan instan/siap saji dimanapun responden berada, serta adanya upacara keagamaan yang sering menyajikan makanan pokok yang beranekaragam di samping nasi/beras. Menurut narasumber dari BKP Kabupaten NTT (2015) menyatakan bahwa dalam upacara keagamaan biasa dihidangkan beberapa jenis makanan pokok dan masyarakat yang menghadiri mengkonsumsinya secara bergantian dalam acara tersebut.

\section{KESIMPULAN DAN REKOMENDASI}

Pola perilaku konsumsi pangan dipengaruhi oleh banyak faktor, baik di DIY maupun NTT. Di DIY, pola konsumsi pangan sudah mengarah pada pola pangan harapan, dengan konsumsi kalori per kapita yang tinggi serta komposisi makanan yang lebih beragam. Sementara di NTT arahnya masih ke penganekaragaman makanan pokok, jumlah asupan kalori per kapita masih rendah dengan komposisi pangan sekitar tiga perempat dari makanan yang dikonsumsi merupakan karbonhidrat/makanan pokok.

Berdasarkan hasil analisis, niat atau intensi IRT dalam menyajikan makanan berpengaruh dan signifikan terhadap pola perilaku konsumsi pangan keluarga baik di DIY maupun NTT karena IRT memiliki peran dan kewenangan yang mutlak dan besar dalam menentukan jenis makanan atau menu yang akan dikonsumsi oleh keluarga.

Di DIY, intensi IRT dalam menyajikan makanan sehat sangat dipengaruhi oleh sikap bahwa mengkonsumsi makanan sehat selain untuk memenuhi kebutuhan gizi tubuh, juga membuat tubuh menjadi sehat. Pemahaman tersebut didapat karena pada umumnya sebagian besar IRT yang menjadi responden memiliki tingkat pendidikan SMA ke atas. Selain itu, dukungan suami dalam bentuk apresiasi ketika IRT menyajikan makanan juga meningkatkan intensi IRT dalam menyajikan makanan sehat untuk keluarga. Adapun sosialisasi PPH baik dari dinas/pemda, organisasi kemasyarakatan serta keagamaan tidak berpengaruh karena sebagian besar dari responden tidak mendapatkan sosialisasi, dan tidak melaksanakan apa yang dianjurkan dalam sosialisasi.

Faktor lain yang juga memengaruhi intensi IRT di DIY dalam menyajikan makanan sehat adalah kontrol lingkungan terutama kebiasaan keluarga yang lebih suka mengkonsumsi makanan olahan sendiri dibandingkan dengan mengkonsumsi makanan siap saji/instan. Dengan adanya kebiasaan tersebut mau tidak mau para IRT dituntut untuk mengolah makanan sendiri 
yang lebih sehat dibandingkan membeli makanan instan/siap saji. Selain itu, pemahaman di lingkungan jika mengkonsumsi makanan sehat berarti turut memajukan sektor pertanian juga berpengaruh dan signifikan terhadap intensi IRT dalam menyajikan makanan sehat. Konsumsi makanan sehat akan meningkatkan permintaan terhadap hasil pertanian karena para IRT dituntut untuk membeli bahan baku makanan yang beragam seperti beras, jagung, kentang, sayuran, telur, ikan dan lainnya.

Sementara di NTT, intensi IRT dalam mengkonsumsi makanan pokok non beras dipengaruhi oleh sikap dan kontrol lingkungan. Faktor yang signifikan dan memengaruhi sikap IRT dalam menyajikan makanan pokok non beras adalah keterampilan responden dalam mengolah makanan pokok non beras serta pemahaman bahwa mengkonsumsi makanan pokok non beras akan membuat tubuh menjadi jarang sakit/selalu sehat. IRT yang memiliki keterampilan memasak makanan non beras cenderung melakukan diversifikasi makanan pokok untuk keluarganya. Berbeda dengan yang tidak memiliki keterampilan memasak, mereka hanya menyajikan nasi karena memasak beras menjadi nasi lebih mudah dibandingkan mengolah jagung atau lainnya.

Sementara faktor kontrol lingkungan yang berpengaruh di NTT diantaranya kebiasaan keluarga mengkonsumsi makanan pokok non beras, kebiasaan mengkonsumsi makanan olahan sendiri dibandingkan makanan siap saji, serta upacara keagamaan. Dengan adanya kebiasaan tersebut maka keluarga susah untuk dapat mengkonsumsi 1 jenis makanan pokok seperti beras, sehingga IRT dituntut untuk menyajikan makanan pokok non beras.

Di NTT, sosialisasi dan himbauan baik dari dinas/pemda, lembaga kemasyarakatan maupun lainnya tidak berpengaruh dan signifikan terhadap intense IRT dalam menyajikan makanan pokok non beras. Hal ini terjadi karena minimnya sosialisasi dari dinas/lembaga kemasyarakatan tentang diversifikasi pangan maupun B2SA/ makanan sehat kepada keluarga di NTT.

Berdasarkan hal tersebut, maka yang perlu dilakukan oleh pemerintah agar perilaku konsumsi pangan sesuai dengan yang diharapkan, antara lain: Pertama, peningkatan sosialisasi tentang pola pangan harapan (PPH) di DIY dan sosialisasi penganekaragaman makanan pokok di NTT. $K e d u a$, adanya pelatihan pengolahan makanan sehat yang bervariasi bagi para ibu rumah tangga karena ternyata keluarga lebih menyukai makanan olahan sendiri dibandingkan dengan makanan instan.

\section{DAFTAR PUSTAKA}

Ajzen, I., \& Fishbein, M. (1975). Belief, Attitude, Intention, and Behavior: An Introduction to Theory and Research. Addison-Wesley, Reading, MA, 129-385.

Ajzen, Icek. (1991). The Theory of Planned Behavior. Organizational Behavior and Human Decision Processses 50, 179-211.

(2005). Attitudes, Personality and Behavior, second Edition. New York: Open University Pres.

Badan Ketahanan Pangan. (2014). Statistik Ketahanan Pangan Tahun 2013. Jakarta.

Baron,R. A. \& Byrne, D. (2005). Psikologi sosial (10th ed). Jakarta: Erlangga

Bloom, D. E., \& Sachs, J. (1998). Geography, Demography, and Economic Growth in Africa. Economic Activity, 2, 207-273. http:// dx.doi.org/10.2307/2534695

Brunner TA, van der Horst K, Siegrist M.(2010). Convenience Food Products: Drivers For Consumption. Appetite, 2010 Dec; 55(3):498-506.

Chapman, K and Ogden, J. (2009). A qualitative study exploring how mothers manage their teenage children's diets. Vulnerable Children \& Youth Studies. 4, 90- 100.

Fogel, Robert W. (2004). Health, Nutrition, and Economic Growth. Economic Development and Cultural Change Journal Vol 52, No 3 PP.643-658.

Jager, W., Janssen, M.A, , De Vries , H.J.M, De Greef , J., dan Vlek , C.A.J. (2000). a Behaviour in commons dilemmas: Homo economicus and Homo psychologicus in an ecological-economic model . Ecological Economics 35 (2000) 357-379. 
Hogg, M., dan Vaughan, G. (2005). Social Psychology, $4^{\text {th }}$ Edition. London: Prentice Hall.

Kelly MP, Bonnefoy J, Morgan A, Florenzano F. (2006). The development of the evidence base about the social determinants of health. Geneva: WHO / CSDH, Measurement and Evidence Knowledge Network.www. who.int/social_determinants/resources/ mekn paper.pdf.

Kotler, Philip \& Keller. (2008). Manajemen Pemasaran Edisi Ketiga belas Jilid 1. Jakarta: Erlangga.

Montana, D.E dan Kasprzyk, D.( 2008). Theory of Reasoned Action, Theory of Planned Behavior and The Integrated Behavior Model . Dalam Glanz, Rimer danViswanath (Ed). Health Behavior and Health Education: Theory, Research, and Practice, $4^{\text {th }}$ Edition. USA: Jossey Bass.
Randall, E., \& Sanjur, D. (1981). Food preferences: their conceptualisation and relationship to consumption. Ecology of Food and Nutrition, 11(3), 151-161.

Retherford, Robert. (1993). Statistical Models for Casual Analysis. USA: Wiley, John\&Sons.

Vindigni, V., Janssen, M.A, and Jager, W.(2002). Organic food consumption A multitheoretical framework of consumer decision making. British Food Journal, Vol. 104 No. 8, 2002, pp. 624-642.

Schubert, L., Jennaway, M., dan Johnson,H. (2010). Explaining of Convenience Food Consumption. Dalam

Lawrence, G., Lyons, K., dan Wallington, T (Ed). Food Security, Nutrition and Sustainability. UK: Earthscan. 